\title{
The Early Neolithic in the Iberian Peninsula and the Western Mediterranean: A Review of the Evidence on Migration
}

\author{
María Cruz Berrocal
}

\begin{abstract}
The first use of domestic plants and animals in the Western Mediterranean has been a matter of debate, since there are no native ancestors for these elements. The current paradigmatic position favors an introduction by human migrants who reached southern France and the Iberian Peninsula through seafaring. The settlers would have introduced the whole economic and cultural Neolithic background. This paper reviews some of the available archaeological, paleobiological and chronological evidence for the Early Neo lithic in the Western Mediterranean, and specifically the Iberian Peninsula, and its use by those who support migration.
\end{abstract}

Keywords Archaeology - Iberian Peninsula - Western Mediterranean · Early Neolithic · Colonization

\section{Introduction}

The study of the inception of the Neolithic is characterised by, on the one hand, lively debates about the problem of rupture vs continuity of ways of life, and on the other hand, discussions around the rate of spread and the homogeneity or heterogeneity of the record (necessarily closely related to the scale of observation). Clear patterns are difficult to observe, and the archaeological record allows virtually dichotomous scenarios to be envisaged. This is particularly so in Europe and the Mediterranean, specifically the Western Mediterranean and the Iberian Peninsula, the objects of this review.

Depending on how societies are understood to be constituted and undergo change, evidence on early farming practices (for example) will be given different interpretive emphases. Ideological and theoretical factors, such as the tension between environmental determinism and culture (e.g. Berger and Guilaine 2009) also play a role. However, the

A first version of this paper was prepared during my appointment as a MEC/Fulbright Postdoctoral Scholar at the University of California, Berkeley, 20062008.

M. Cruz Berrocal $(\bowtie)$

IH, CCHS, CSIC, c/Albasanz 26 28, 28037 Madrid, Spain

e mail: maria.berrocal@cchs.csic.es 
polarization of the Neolithic debate seems to be ultimately fuelled by a particularly underdetermined archaeological record that allows equifinal explanations. Part of the problem, now increasingly acknowledged, is that there are breaks in the European and Levantine archaeological record that some authors relate to the $8.2 \mathrm{ka}$ event (the rapid climatic cooling at c. 8200 BP) (e.g. Berger and Guilaine 2009; Weninger et al. 2006).

The big issue underlying these European debates is, of course, demographics: whether or not migration of new populations took place, whether or not there was exceptional population growth, how these demographic issues developed, and to what extent they explain or are a consequence of change (e.g. Boyle and Renfrew 2000; Bocquet Appel 2002; Pinhasi and Pluciennik 2004; Bocquet Appel and Naji 2006; Cohen 2009; Gignoux et al. 2011). The migration vs cultural diffusion debate has been run in almost every European region, while in the Levant the discussion has centered around the issue of continuity vs rupture. On the basis of existing evidence, the Natufian and preceding phases have been seen either as a revolutionary event or as a rapid response to changing conditions following a major socioeconomic crisis (Bar Yosef and Belfer Cohen 1992, pp. 39 40), or, more recently, as a long term process in which permanent communities were formed first, with farming subsequently emerging as by product of the necessity of feeding large numbers of people (Watkins 2010). These recent developments are particularly pertinent and should impact research on the Early Neolithic in Europe, which has always been seen as a function of the Neolithic in the Levant regarded as the ultimate source of any cultural, social or demographic process. But as Watkins (2008, p. 147) points out, the 'Levantine Primacy Illusion' (the generally accepted orthodoxy that the Levantine corridor is where the earliest cultivators, and plant and animal domesticates, are to be sought) still governs the debate, despite serious doubts as to its accuracy (Watkins 2008, pp. 149 150).

It is foreseeable that an abandonment of the 'revolution' paradigm in the Levant and an embracement of a view stressing a long term process will affect current migrationist paradigms in Europe, especially regarding the speed of the alleged migrations. My own view of the Early Neolithic in the Iberian Peninsula is closer to Watkins's long term vision than to revolutionary models.

For the moment, dichotomous views of the transition to the Neolithic endure in different regions, especially in relation to the pace of change. In Scandinavia, Price and Gebauer (1992) see gradual change through long term processes, minimizing any perceived rupture (such as that argued for by Zvelebil and Dolukhanov (1991), for instance). But most archaeologists perceive the transition as a rapid transformation, based upon the sudden and simultaneous appearance of domesticates and TRB (Funnel Beaker Culture) characteristics all over southern Scandinavia (Price and Gebauer 1992, p. 110). Recent genetic data highlight an alleged lack of continuity between hunter gatherers and modern populations in Scandinavia (Malmström et al. 2009).

In Central Europe, the Early Neolithic LBK (Linear Pottery Culture) complex is characterized by new features in lithic technology, ceramics, house plans, settlement location and mixed farming subsistence strategies, all of kinds previously unrecorded. The source of these new elements would be the migration of farmers, who would follow major river valleys, taking advantage of the fertility of loess soils. But again a major issue has been the rhythm of this process. Recently, Shennan and Edinborough (2007) have proposed that increasing LBK site numbers support demic diffusion, on the basis of analysis of ${ }^{14} \mathrm{C}$ dates. According to Keeley (1992, p. 87), again on the basis of radiocarbon dates, the migration was extremely rapid and took only 200300 years from central to northwestern Europe. According to other accounts, LBK expansion 'from the Hungarian Plain to the 
Netherlands ... [and] the spread of farming through the British Isles, both extending over c. $1,000 \mathrm{~km}$, occurred in less than two centuries' (Bonsall et al. 2002b, p. 9).

Issues of chronological control when using radiocarbon for tracking short term events notwithstanding, this is an extremely short time and raises questions about the reproductive ability of farming communities (for instance). This has led researchers to emphasize the role potentially played by local communities in the Neolithisation process (see e.g. Bogucki 1996; Zvelebil 1989; Price and Gebauer 1992; Lemmen et al. 2011). In fact, the shifting features of the record at the regional scale (Oross and Bánffy 2009; see also: Zvelebil 1989; Bogucki 1996; Sherratt 2004) seem to be better explained by transitional processes in which foreign and indigenous elements interact in complex ways. Trans danubia is a particularly pertinent example, in which an 'integrationist' approach is used to account for continuity of subsistence strategies, and slow transformation seems to alternate with periods of dynamic transformation (Oross and Bánffy 2009).

Genetic data, on the other hand, which are relatively abundant for Central Europe, tend to show contradictory results (Richards et al. 2000; Achilli et al. 2004; Dupanloup et al. 2004; Soares et al. 2010; Haak et al. 2010; Galeta et al. 2011). Nonetheless, there is a strong indication of a genetic discontinuity between LBK populations and both their Mesolithic neighbours and modern European populations. Genetic data are, however, from an archaeological viewpoint, difficult to interpret in certain contexts (see below).

Despite these difficulties, the LBK archaeological record appears homogeneous when compared to the Western Mediterranean archaeological record, my focus here. In the former, the record tends to show spatial patterns (mostly following rivers), while these are pretty much absent in the latter, and material culture presents much more variability.

The Western Mediterranean can be considered a single region from the point of view of Early Neolithic diagnostic archaeological elements. I will deal specifically with the Iberian Peninsula, which enjoys an almost insular status within the area. The Iberian Peninsula, the westernmost area of Neolithic expansion in the Mediterranean, has probably seen the greatest increase in research, ${ }^{14} \mathrm{C}$ dates and number of sites in the region in recent years. A large part of the evidence concerning the Early Neolithic has been produced and inter preted by researchers within the migrationist paradigm, and especially according to the 'maritime pioneer colonization' model (Zilhão 2001), elaborated for the Early Neolithic Cardial Ware Culture (hereafter 'the Cardial'), which, although increasingly questioned (e.g. Manen and Perrin 2009, p. 437; García 2010), remains the dominant position, with its assumptions held to be truths in other contexts. Therefore, an important part of this paper will be devoted to the analysis of some of this evidence and its treatment.

This analysis has a broader dimension as the debate on local vs exogenous origin and processes in Europe has been extrapolated to other regions of the world; for instance, Southeast Asia (Miriam Stark, personal communication) and New Guinea (Haberle 2003). The Western Mediterranean Early Neolithic has also been compared with the Lapita expansion (Ian Lilley, personal communication), while, interestingly, the Lapita coloni zation has been used as a parallel to the Western Mediterranean alleged colonization (Zilhão 2001, 2003).

\section{Premises}

The first appearance in the archaeological record of the Western Mediterranean of food producing economies based on domestic cereal, sheep and goats, was the focus of vigorous 
debate throughout the twentieth century. Early proposals saw the Neolithic originating in North Africa, and spreading from there to the Iberian Peninsula. In the mid 1940s, the 'origin' shifted into the Levant (see Hernando 1999 for an extensive review of the his toriography of the Iberian Neolithic). As stated above, it is generally agreed that the origin of the domesticates in the Western Mediterranean is in the Near East, since there are no native ancestors in the region (e.g. Zapata et al. 2004). The issue then has become to explain the east west transmission of the domesticates, and in the Western Mediterranean, the relatively 'abrupt' appearance of the diagnostic features of the Early Neolithic in the archaeological record impressed pottery, both the Impressed Ware Culture (the Impressa) and the Cardial, together with the use of domesticates and traces of village life has been traditionally explained through colonization. Whether by land or by sea, it would be the arrival of people from the east that would trigger the Neolithisation process, or the tran sition from Mesolithic hunting and gathering to agricultural economies. Although (drawing from anthropology, e.g. Bernabeu et al. 1993) different possible interactions between colonizers and indigenous peoples have been proposed, in order to introduce necessary nuance into the picture, the core of the hypothesis remains anchored to alleged demo graphic events.

In short, the archaeology of the Early Neolithic in the Iberian Peninsula and the Western Mediterranean has traditionally been characterised by two conspicuous factors, which were present during the sixth millennium BC: the simultaneous appearance of pottery, domestic animals and plants (the 'Neolithic package'); and the appearance of fully Neolithic ex novo sites, which can be relatively complex settlements, with significant structures such as ditches or clusters of pits.

These elements tend to 'punctuate' the landscape, rather than totally erasing the pre vious archaeological record. In the classic account of the Neolithic, mainly based on the archaeology of the Mediterranean basin, Neolithic and Mesolithic settlements and material culture share, broadly speaking, the same territory, but they largely 'ignore' each other for several reasons (a characterisation that has been subsequently demonstrated to be inap plicable in other areas of the peninsula with somewhat later chronologies).

This apparent lack of connection between the Neolithic and the previous record has been the key basis for proposing a colonization that would have introduced the new food producing techniques and way of life into the Peninsula. Later on, these new ways would have extended throughout the Iberian Peninsula (and for that matter, the rest of Western Europe), through direct and/or indirect acculturation (e.g. Fortea 1973; Martí and Her nández 1988; Bernabeu et al. 1993; Bernabeu 2002, among many others).

These authors would acknowledge a certain degree of economic preadaptation to food production among hunter gatherers in the Late Mesolithic, for instance through animal management (Bernabeu et al. 1993; Martí and Juan Cabanilles 1997), which might have eased the process of acculturation. But the 'Neolithic package' is used by the supporters of migrations as a self evident argument for an influx of foreign people (e.g. Bernabeu et al. 1993, 2001). Together with the lack of wild agriotypes and the fact that the record does not show a linear sequence of change, this position probably owes much to the dominance of culture history in Spanish archaeology, in which migrations have typically been the favoured explanation for material culture variability (especially for this kind of narrow chronological window).

Ammerman and Cavalli Sforza's (1984) 'wave of advance' put forward a slow ter restrial diffusion as the main vector of colonization: every new generation of farmers would have gained some land by moving a little bit further from their ancestors' land, thus eventually reaching the westernmost extremes of Europe. However Zilhão (2001, 2003) 
noted that this process simply could not have happened in the Western Mediterranean, and especially in the Iberian Peninsula, because radiocarbon evidence supports a faster process than traditionally supposed. He proposed instead a maritime colonization the 'maritime pioneer colonization' model enacted by small groups of farmers sailing along the coast of the Western Mediterranean and settling in certain places, forming little agricultural enclaves that would trigger the Neolithisation process in those areas. This hypothesis has partially replaced the 'wave of advance' model in the Western Mediterranean (e.g. Ber nabeu 2002; Bernabeu et al. 2003; McClure et al. 2008).

New research has pointed out the problems of the 'maritime pioneer colonization' model (Manen and Perrin 2009; García 2010), especially as it was defined for the Cardial Neolithic. A 'demographic transition' has therefore been advanced, meaning a slower demographic expansion phenomenon, leading to a progressive re shaping of the value system ('phénomène d'expansion démographique, plus lent, induisant une recomposition progressive du système de valeur': Manen and Perrin 2009, p. 437) of the Mesolithic societies, a 'wave of advance' model revisited, in combination with an alleged previous maritime colonization, all of it largely based on the ceramic evidence (see below).

The alternatives to the colonization model, such as the 'capillary' or 'percolative' model (Vicent 1990, 1997; see also: Rodríguez et al. 1995; Hernando 1999), put the emphasis on social continuity and the role of hunter gatherers in the Neolithisation process. They did not rely on local domestication, but on the slow introduction of the Early Neolithic ele ments, domesticates and pottery, through interaction and exchange among hunter gather ers, who would use them as prestige objects. Vicent (1997), from a materialist perspective, discriminated the arrival of these prestige elements from the process of origin and con solidation of the productive economies. The domesticates had the potential to subvert the social order due to their creation of surplus value; they would therefore have interfered with the local social and political dynamic, ultimately leading to the transition to the farming economy.

Since none of the positions on the Neolithic is fully proved through the archaeological record, an epistemological argument may apply: the alternative models for Neolithisation that rule out migrations are theoretically stronger because they are parsimonious; they do not require unknown entities as actors, and they reduce the number of factors in the explanation (Vicent 1990). In this case, change as a locally based indigenous process could be considered the 'null hypothesis' (Vicent 1990). The burden of proof would then fall on the supporters of the demic hypothesis.

These models were at the height of their popularity during the 1990s, with new research still pointing to the underdetermined character of the demic hypotheses (e.g. Díaz del Río 2010). The model remains unfalsified by the archaeological evidence, but in a secondary position, in part because researchers supporting migrations have actively pushed forward their approach through new evidence and synthesis. Therefore, demic hypotheses still function as the paradigm in the Neolithic of the Western Mediterranean. In this paper, I refer to them as paradigmatic or migrationist models.

In all of these models, population arrivals are the trigger for the Neolithisation process. The fundamental factors that would support the model (Bernabeu 2006, pp. 198 199) are: (a) a clear east west chronological gradient from Italy towards the Iberian Peninsula; (b) a rapid pace of expansion; (c) distinct genetic pools representing indigenous and the migrant populations; (d) a well established expansion route (through the northern Mediterranean; but new works are proposing a southern pathway through Morocco); and (e) a clear break with the Mesolithic. In short, paleobiological, chronological, and archaeological evidence, especially a shared material culture type in the Early Neolithic, implying the existence of a 
'formative' period (Bernabeu et al. 2009). It is important to make explicit that these criteria have been advanced by the migrationists in order to test their hypothesis, and the available evidence has mainly been produced within this migrationist matrix. But the evidence is not straightforward.

I will not discuss topics such as the meaning of 'Mesolithic' and 'Neolithic' and their accuracy as descriptors of an alleged binary reality; I will rather keep these categories and discuss the authors' data in their own terms. I will, however, deal briefly with two diffi culties associated with the study of the Mesolithic Neolithic transition.

The bulk of the evidence has traditionally come from caves and shelters. This leads to an argument concerning 'apparent archaeological contexts' (Bernabeu et al. 1999): sites with old dates for Neolithic deposits, or with traces of a gradual transition, have been dismissed as post depositionally problematic. Bernabeu et al. (2001) analyzed animal bones from a series of sites belonging to the Mesolithic Neolithic transition, leading to a classification into three patterns: (1) Mesolithic; (2) Neolithic; and (3) mixed. The treat ment of wild and domestic bones differed distinctly between groups 1 and 2, while group 3 was a combination, or mix, of both patterns. Therefore, group 3 was dismissed as arising from deposits that were palimpsests. However, the three groups were defined based on the same sites, where only certain layers were assumed to be mixed. Since these stratigraphic layers were defined by their excavators on the basis of the diagnostic materials they contained, the argument becomes problematic.

There may certainly be an important taphonomic problem in the Mediterranean basin right at the boundary between the Mesolithic and Neolithic, possibly related to the $8.2 \mathrm{ka}$ event (Bonsall et al. 2002a; Weninger et al. 2006; Berger and Guilaine 2009). For this reason, we need to 'quarantine' suspect sites, especially if they are demonstrated to be stratigraphic palimpsests, instead of using them to define the existence of Mesolithic vs Neolithic patterns.

A second example of the difficulties inherent in the study of the transition is represented by Bocquet Appel (2002, pp. 638 639). While trying to determine whether there is a demographic transition at the Mesolithic Neolithic boundary in Europe, Bocquet Appel makes the a priori assumption that 'Basically, the scarcity of the sampled Mesolithic cemeteries is a reflection of the small size of the Mesolithic population itself, and there is not much that can be done about it.' Critically, we may note that studies of this kind tend not to take into account the potential for different burial behaviours between different populations.

\section{Ceramics}

The paradigmatic material culture of the Early Neolithic in the Western Mediterranean has traditionally been a type of impressed pottery called Cardial pottery. The 'maritime pioneer colonization' model was basically advanced as an explanation for remains of this kind, as they were widespread in the region, from Portugal to Italy. Of course, the core of the model rested on the assumption that this pottery was one that is, that the record was homoge neous and therefore the idea of a Neolithic package (unique pottery production, plus domesticates) was meaningful. The logical consequence of this would be the possibility of tracing this material culture to its eastern origins, basically in Italy.

But the homogeneity of Cardial ware was more assumed than discussed. No clear origin has ever been traced for the pottery, and more and more variability within the assemblage has been highlighted. Issues include: differences between the Mediterranean and Atlantic 
coasts of the Iberian peninsula (Manen et al. 2007); a high degree of variability within the Franco Iberian Cardial ware (van Willigen 2007; van Willigen et al. 2008); differences both between and within Franco Iberian Cardial and Italian Cardial (Manen and Perrin 2009); regionally specific features of the Portuguese pottery (Zilhão 2009), and more generally, the Portuguese Early Neolithic pottery as a whole (Carvalho 2010); and overall, problems of assessing the different decorations allegedly typical of various parts of Italy, found on sites on the Mediterranean shores of the Iberian Peninsula (Bernabeu et al. 2009; Bernabeu and Molina 2009).

Within this complex panorama, one type of pottery has recently attracted the attention of researchers. This is the Impressa ware, increasingly considered the first stage of the Neolithisation process in the region (e.g. Guilaine et al. 2007; McClure et al. 2008; Ber nabeu et al. 2009; García 2010). This is a reversal from all previous research (e.g. Ber nabeu 2006), which sought to demonstrate that Cardial ware was the first symptom of a Neolithic presence in the region. In fact, the 'maritime pioneer colonization' model tried to explain the distribution of the Neolithic package, primordially understood through Cardial ware (Zilhão 2001). In this new light, the Impressa ware would belong to an original episode of colonization from Italy, while the Cardial ware would belong to a period of consolidation of Neolithic life, the product of 'structured expansion', in which the socioeconomic system is better integrated and incipient social hierarchization is observed (García 2010, p. 50). Not only that, but the Cardial 'culture' would now be the product of the various foreign peoples taking part in this 'formative' episode, their different impact, and the interactions among them and with their Mesolithic neighbours (Bernabeu et al. 2009, p. 93; Bernabeu and Molina 2009, p. 201), starting therefore to look like a virtual indigenous/local process.

Thus, Cardial ware has been used as a demonstration of a pioneer maritime coloniza tion, and also now as evidence of a fully agricultural society developing autochthonously. Thus it seems that migrationist models can be argued for or opposed independently of the materiality of the archaeological record.

For the moment, this record shows much more regional variability than would be expected under maritime colonization premises. Moreover, the Impressa pottery itself is still only weak evidence in support of the model. Its occurrence is very patchy, although always in combination with Cardial and other types of impressed wares, in a very few sites located in the Mediterranean coast of the Iberian Peninsula, some of them dubious according to the migrationist authors themselves: El Barranquet; Mas d'Is; Cova d'En Pardo; Cova de les Cendres; Cova de l'Or; Abrigo de la Falguera; and possibly Cova de la Sarsa (Bernabeu and Molina 2009; Bernabeu et al. 2009; García 2010). Under these circumstances, a claim to temporal precedence over Cardial ware is feeble (Bernabeu et al. 2009; García 2010). In fact, the only acceptable interpretation at this point is that Cardial and Impressa are contemporaneous (see Bernabeu et al. 2009; Bernabeu and Molina 2009). This means that the dates for the Impressa in the Iberian Peninsula are much younger than those for the Ligurian Impressa ware, the alleged source for the former (see Manen and Perrin 2009; van Willigen 2007).

This heterogeneous panorama of apparently regional pottery groups, found in combi nation in the same archaeological sites at contemporary dates, is quite at odds with the expectations created by a model that posits rapid, long distance colonization. The model necessarily requires a 'formative' period to confirm it. The impressed ware of course displays a resemblance when viewed at the scale of the entire Western Mediterranean; but variability tends to increase as we approach a more detailed scale. The Neolithic package seems to be diverse; this is not surprising, as even in known migratory events material 
culture presents great variability (see Addison and Matisoo Smith 2010 for the Lapita complex). But it would be desirable for researchers to produce a working scenario for the material culture, the pottery in this case, that demonstrates a migration model. Otherwise research seems to work on ad hoc proposals, especially because formal relationships within pottery (what resembles what, what comes from where, what is the formal origin of what) are given such a strong role that they are in themselves the explanation of the Neolithic. Thus, extremely scarce fragments of pottery disseminated in a few sites are able to effect a disproportionate impact on the model. In particular, we should reconsider why the fugitive appearance of pottery such as Impressa, not formally attested in the Iberian archaeological record, could possibly be taken as the material remains of an event that triggered such a rapid and massive historical process as the Neolithisation of the Iberian Peninsula. It is not more ceramic evidence that is needed, but more sophisticated theorisation about history and social processes.

\section{Human Biological and Genetic Data}

The available human bioarchaeological information can be broadly classified as mor phological, genetic and dietary. It is scarce, and not totally supportive of population contribution or replacement. As for morphometric data, Lalueza found that:

the Mesolithic Neolithic transition in the Iberian Peninsula did not represent a sharp disruption in the pattern of stature increase and caries increase ... from the Meso lithic to the present. In contrast, cranial capacity ... does not show a progressive increment from the Neolithic ... However, differences between the Mesolithic sample (Muge) and the Neolithic and post Neolithic samples are clear for this trait ... It is interesting that the other Mesolithic sample available, that from Oliva, does not seem to show this low neurocranial size. (Lalueza Fox 1996, p. 691)

Therefore, on the basis of a single piece of evidence of cranial size from Muge (Por tugal), he stated that

the morphological changes observed suggest that the spread of the Neolithic in the Iberian Peninsula involved an important replacement of the population. (Lalueza Fox 1996, pp. 693 694)

Lalueza's results in relation to dental caries increase, though, are exactly at the opposite extreme to those found by Lubell et al. (1994). Further, his (1996) work was questioned by Jackes et al. (1997a) on the basis of sample problems: Lalueza's Mesolithic sample was apparently incomplete. More importantly, his Neolithic and Mesolithic sample was drawn from sites all over the Iberian Peninsula, therefore comparing things that are a priori non comparable. As Jackes et al. (1997a, p. 841) point out, it is reasonable to say that

samples used in any attempt to identify biological continuity or discontinuity at the Mesolithic Neolithic transition must be derived from the same general area. (Jackes et al. 1997a, p. 841)

Jackes et al. analyzed Lalueza's data, as well as their own samples, and concluded that the suggested congruency of craniometric data to a demic diffusion model is illusory. (Jackes et al. 1997a, p. 844) 
Lalueza and González (1998) replied by questioning the samples used by Jackes et al. (1997a): they were allegedly too few and inaccurate in terms of sex ascription. Lalueza and González subsequently insisted on the existence of discontinuities due to migration, which

even if rather restricted genetically ... could have had a strong impact on cranial morphology. (Lalueza and González 1998, p. 512)

Also dealing with cranial data for the Western Mediterranean, Pinhasi and Pluciennik commented:

The results display great heterogeneity among the Cardial Neolithic groups, with Cardial specimens morphologically associated with both Early Neolithic and Mesolithic groups, and show that, in this region at least, cultural groupings do not map neatly onto biological populations. The lack of a satisfactory sample size and geographic coverage for Mediterranean Early Neolithic specimens precludes closer examination of potential specific areas of admixture (but see Lalueza Fox 1996; Jackes et al. 1997b). Our current analysis suggests, if anything, great variability in biological (and potentially other) relationships and processes within and between the various groups. (Pinhasi and Pluciennik 2004, p. 69)

Therefore, the results are not conclusive, first because the available samples are rela tively small and widespread, and second, but very importantly, because these samples do not necessarily randomly represent the entire population: the crania belong to people who were interred, and we lack the criteria according to which someone could or could not be subject to this ritual. Thus we are unable to evaluate the biological variability of populations.

As for genetic data, there are a number of studies that deal with the European gene pool and the genetic evidence for migrations, either Palaeolithic or Neolithic. Their results are diverse; more interestingly, their assumptions, hypotheses and procedures are equally diverse.

The genetic evidence itself presents important issues. Usually, non recombining DNA is used (Y chromosome or mitochondrial DNA), which raises questions as to the validity of the results, since they represent only a uniparental mode of inheritance (Y chromosome from father to son, and mitochondrial DNA from mother to children), and, potentially, differential mating behaviour between the sexes. An alternative method uses a combination of different genetic evidence encompassing the entire genetic variance (e.g. Dupanloup et al. 2004).

Both approaches have been used to understand the current European gene pool. They normally try to establish one of two possibilities: that the European gene pool derives mostly from Palaeolithic populations; or that it largely derives, or received an impact from, migrant Neolithic populations.

This kind of analysis of current genetic patterns is limited by the difficulty in dating them. Even when dated, it is not easy to define the exact phenomenon being dated (origin of a genetic marker, arrival of a population, etc.). More interesting from our point of view is that most work assumes that there were two relevant migratory events in European population history (a Palaeolithic colonization/recolonization, and a Neolithic migration) that can explain the current genetic evidence. Therefore, the research is designed to assess which of the two events contributed more in this context.

Unfortunately, the results tend to be inconsistent and even contradictory, with estima tions of migratory impacts in Europe, especially Neolithic migrations, varying widely (e.g. 
Richards et al. 1996, 2000; Simoni et al. 2000; Semino et al. 2000, 2004; Chikhi et al. 2002; Achilli et al. 2004; Dupanloup et al. 2004; Rootsi et al. 2004; Currat and Excoffier 2005; Gamble et al. 2005; Belle et al. 2006; Karafet et al. 2008; Haak et al. 2010; Soares et al. 2010; Galeta et al. 2011; Lacan et al. 2011).

In the Western Mediterranean Neolithic, the essential question is whether or not there were population movements worthy of the name migrations. Ancient DNA analyses are useful, but little work has been done in this regard for the Early Neolithic in the Iberian Peninsula, and what has been done has always been based on mitochondrial DNA.

Sampietro et al. (2007) analyzed 11 Neolithic remains from one site, Can Grau, in Catalonia, dated to $35003000 \mathrm{cal} \mathrm{BC}$. They found no notable genetic differences between the Neolithic remains and the current Iberian population, so they infer a large Neolithic migration that would explain the continuity between the two populations. Their main argument relies on the contrast between these results and those of Haak et al. (2005). This analysis of ancient mitochondrial DNA on Central European Neolithic remains showed a remarkable difference between these and the current European population, thus leading the authors to propose that:

the first farmers ... had limited success in leaving a genetic mark on the female lineages of modern Europeans. This is in contrast to the success of the Neolithic farming culture itself, which subsequently spread all over Europe ... One possible explanation is that the farming culture itself spread without the people originally carrying these ideas. This includes the possibility that small pioneer groups carried farming into new areas of Europe, and that once the technique had taken root, the surrounding hunter gatherers adopted the new culture and then outnumbered the original farmers, diluting their N1a frequency to the low modern value. (Haak et al. 2005, p. 1017)

The small scale migration proposed by Haak, Forster et al. would explain why there is no trace of these hypothetical groups in the subsequent populations Haak et al. (2010) corroborate this lack of relation between the LBK Neolithic population and modern European populations, finding a link between LBK and modern day Near East and Ana tolian populations. They subsequently infer that the former had their origin in those regions. This interpretation is of course mediated by the preeminence of models relying on Neolithic migrations. Otherwise, the most parsimonious inference would have been that modern Near East populations derive from ancient LBK populations. The work of Haak et al. (2005) has been criticized for its use of mtDNA, its small sample, and the overin terpretation of results by extrapolating them on to the whole of Europe.

But based on all these results, Sampietro et al. (2007) propose that cultural diffusion explains the Neolithic in Central Europe, while the Neolithic in the Mediterranean must be explained through demic diffusion, which is quite a reversal from all previous attempts to explain the LBK Neolithic. It is also problematic: Sampietro et al. (2007) have found no evidence of a Middle Eastern origin for the Catalonian Neolithic population they study. In fact, they have no means to falsify the hypothesis that the population did not arrive from elsewhere: they have no place of origin for it, and most importantly, they did not analyze 'Mesolithic' or 'Palaeolithic' Iberian populations. As happens with the works based on the null hypothesis of two migrations into Europe, Sampietro et al. (2007) work on the assumption that there was a Neolithic migration, but they cannot discard the hypothesis that Mesolithic and Neolithic could potentially be the same population.

Chandler et al. (2005) did analyze Neolithic and Mesolithic populations in Portugal. They found that 
the ancient Portuguese haplogroup frequencies are more closely related to Iberian and Mediterranean populations than to Near Eastern populations. This is true even for the early Neolithic population. It is also notable that the Portuguese Mesolithic and Neolithic samples contain no haplogroup J, that is, no marker of Near Eastern population input... However, the MDS plot shows that the Mesolithic and Neolithic populations are not themselves closely related. This comparison indicates that they are genetically distinct populations. (Chandler et al. 2005, p. 784)

As with the work of Sampietro et al. (2007), it is important to pay attention to the details of sampling. Sampietro et al. (2007) analyzed 11 individuals from one Neolithic site, potentially about a millennium younger than the earliest known Neolithic sites in the Peninsula. The kind of sample used by Chandler et al. (2005) (Fig. 1) can be inferred from their relative recovery: 24 individuals for the Neolithic and 11 for the Mesolithic. The Neolithic individuals come from three sites, while the Mesolithic individuals come from seven sites. Five of these are in the same valley, while the other two are $100200 \mathrm{~km}$ apart (as the crow flies). This means that the samples may come from potentially different cultural regions, especially due to the fragmentation of the Mediterranean area (Horden and Purcell 2000). All of them were, however, labeled 'Mesolithic' (the fact that the comparative samples were classified as 'Mesolithic', 'Neolithic', 'Portuguese Neolithic', 'Portuguese Mesolithic', 'Portuguese', 'Iberian', 'Catalan', 'Italian', 'Mediterranean' and 'Near Eastern' (Chandler et al. 2005, p. 785), most of which are overlapping categories, hardly helps clarify their historical significance).

\begin{tabular}{|c|c|c|c|c|c|c|c|c|c|c|}
\hline & \multicolumn{3}{|c|}{ Neolithic } & \multicolumn{7}{|c|}{ Mesolithic } \\
\hline & $\mathrm{ABS}$ & Caldetirio & Perdigōes & Ara & $\operatorname{CdA}$ & CdP & PSB & Tol & Fia & VOR \\
\hline Samples extracted & 49 & 17 & 9 & 10 & 5 & 7 & 5 & 1 & 2 & 6 \\
\hline No DNA & 31 & 0 & 1 & 7 & 2 & 1 & 4 & 0 & 0 & 2 \\
\hline Failed or inconsistent & 9 & 4 & 0 & 1 & 2 & 1 & 0 & 0 & 0 & 4 \\
\hline One sequence only & 5 & 0 & 1 & 0 & 0 & 1 & 0 & 0 & 1 & 0 \\
\hline Reproducible & 4 & 13 & 7 & 2 & 1 & 5 & 1 & 1 & 1 & 0 \\
\hline Pereentage recovery & 8 & 77 & 78 & 20 & 20 & 71 & 20 & 100 & 50 & 0 \\
\hline
\end{tabular}

Tabie 1. Summary of extraction and sequencing results for Mesolithic and Neolithic sites. ABS-Algar do Bom Sunto; CdA - Cabego das Amoreiras; Cap - Cabeco de Pez; PSB - Po ças de Sro Berro, Tol - Toledo;

B Fia. Fiais VAR - Vale de Romeras

\begin{tabular}{|l|l|l|l|}
\hline Period & Sïte & Geographical setting & $B C$ dates \\
\hline \multirow{4}{*}{ Mesolithic } & Arapouco & Sado Valley & $6000-5750$ \\
\cline { 2 - 4 } & Vale de Romeiras & Sado Valley & $6000-5750$ \\
\cline { 2 - 4 } & Poças de São Bento & Sado Valley & $5500-5250$ \\
\cline { 2 - 4 } & Cabeço do Pez & Sado Valley & $5500-4750$ \\
\cline { 2 - 4 } & Amoreira & Sado Valley & $5000-4750$ \\
\cline { 2 - 4 } & Toledo & (Vimeiro) Lisbou & $8000-7000$ \\
\cline { 2 - 4 } & Fiais & Algarve & $6000-5250$ \\
\hline \multirow{4}{*}{ Neolithic } & & & \\
\cline { 2 - 4 } & Caldeirio & Tomar & $6100-4800$ \\
\cline { 2 - 4 } & Algar do Bom Santo & Abrigada (Lisboa) & $3900-1700$ \\
\cline { 2 - 4 } & Perdigōes & Evora & $3500-$ \\
\hline
\end{tabular}

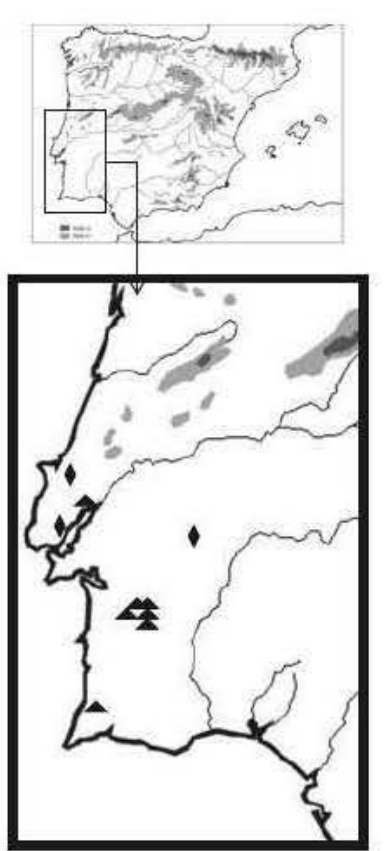

Fig. 1 a Samples used in the DNA analysis by Chandler et al. (2005, p. 784). b Summary of chronological and geographical information about the sites used by Chandler et al. (2005) (Duarte 1998; Lago et al. 1998; Araújo 1998; Zilhão 1998b). The map shows the approximate location of Mesolithic (filled triaangle) and Neolithic sites (filled diamond) 
In terms of chronology, the Mesolithic samples are completely disparate, covering a possible time span of about 3,000 years (or 120 twenty five year periods/generations). The Neolithic dates are similarly disparate, potentially spanning about 4,000 years, or 160 twenty five year periods/generations (Duarte 1998; Lago et al. 1998; Araújo 1998; Zilhão 1998b). (It is worth noting that Sampietro et al. [2007, p. 2166] regard 2,000 years as sufficient time to explain the genetic difference between their sample and that of Haak et al. [2005]).

Based on their analysis, Chandler et al. could not verify a Near Eastern origin for the Neolithic populations. They found that

ancient Portuguese populations... are not derived directly from a Near Eastern source population [and therefore] the low resolution of mtDNA means that a source population for the Neolithic farmers may never be conclusively identified. (Chandler et al. 2005, p. 786)

This is of interest because this kind of evidence had previously been regarded as the way to demonstrate the migration:

the hypothesis that demic expansion is associated with the transition to farming in West Mediterranean Europe does not require homogeneous populations as the end result of the process. If people moved along with domestic resources, it should be possible, using Iberian fossil samples, to establish mtDNA or Y chromosome lin eages extending to the earliest Neolithic of the Fertile Crescent, where wheat, barley, sheep, and goats were first domesticated and from where they spread into Europe. If Iberian Early Neolithic people were shown to belong to such lineages and Iberian Mesolithic people were shown to be different in this regard, population movement would be proved. (Zilhão 1998a, p. 690)

Chandler et al. did, however, find a difference between Neolithic and Mesolithic populations:

while the Mesolithic and Neolithic sequences are not hugely divergent, they share only one haplotype. A single inter breeding population would be expected to share many more haplotypes. (Chandler et al. 2005, p. 785)

The question is whether one would expect to find inter breeding between two popula tions potentially living in different time periods and regions. According to the authors, these results may be explained by the proposition that the Neolithic populations in Portugal came from other places in the Mediterranean where they had been acculturated by previous settlers, and so on. These groups of people would have leap frogged through the Western Mediterranean and into Portugal.

In this model, agricultural enclaves were formed by groups of leap frogging sea faring colonists who moved around the Mediterranean coast. The source population however is not Near Eastern, as demonstrated both by the absence of haplogroup J in the Portuguese Neolithic population and by the genetic distance observed between the Neolithic Portuguese and Near Eastern populations. More likely, a Mediterranean group which itself had adopted farming through exchange or only limited migration moved into the uninhabited parts of Portugal's coastal regions to pursue an agri cultural subsistence strategy. (Chandler et al. 2005, pp. 785 786).

But the length of these different episodes of colonization and acculturation is not determined by the authors (Chandler et al. 2005, p. 786). They do not make clear whether it 
was a single group, or different groups of leap frogging sea faring colonists who reached the coasts of Portugal.

A single, small group is unlikely to have been able to pursue a colonization strategy on its own. Different groups from different parts of the Mediterranean cannot be expected to be genetically homogeneous, as the authors imply. So if Mesolithic populations are internally more similar to each other than they are to Neolithic populations in Portugal, and vice versa, this might be taken as evidence against colonization, rather than in favour of it.

Finally, Chandler et al. found that:

Haplogroup frequencies and genetic distances show that the ancient Portuguese populations studied here, both Mesolithic and Neolithic, are most closely related to the modern Basque and Galician populations of the Iberian Peninsula. (Chandler et al. 2005, p. 785)

This finding has two implications, from our point of view. First, it brings into question the argument advanced by Sampietro et al. (2007), which sought to demonstrate Neolithic migration through the alleged continuity between the ancient Neolithic population and the current Iberian gene pool. In the study by Chandler et al. (2005), both Neolithic and Mesolithic populations are related to the current population in the peninsula. Secondly, it brings to the fore the problem of time depth when comparing populations. In this case, $8,00010,000$ years render a much greater similitude among populations (ancient and modern) than a comparison between two ancient populations within a shorter span of time.

Fernández et al. (2010) analyzed an undefined number of samples in terms of their distribution per site, from 26 archaeological sites in the Near East, southern France and the Iberian Peninsula. Their results point to a break in the continuity of population both in the Near East and the Iberian Peninsula since the Neolithic (modern populations in both regions do not derive, apparently, from Neolithic populations), and to a contribution of population from the Near East into the Iberian Peninsula during the Neolithic. In another study (Gamba et al. 2011), cultural and genetic connections between northeastern Iberia and the Near East are again stressed, but the arrival of pioneering small groups from the Near East in an advanced moment of the Early Neolithic, as shown by the dates of Can Sadurní, contradicts other kinds of evidence, and does not fit well in any migrationist model for the Neolithic currently accepted for the Western Mediterranean.

This general overview shows that genetic and morphometric data present difficulties when used as independent arguments in the debate on the colonization of the Western Mediterranean: they do not yet allow us to choose between two hypotheses (see also Bocquet Appel and de Miguel 2002). The final interpretation of this kind of evidence, is, rather, a function of an author's position, which may lead to circularity.

Diet has been a third controversial argument for the distinction between Mesolithic and Neolithic populations during this transitional period. Stiner et al. (2003) showed continuity without quantitative changes in the exploitation of marine shellfish in the Portuguese region of the Algarve. They proposed a continuity of diet without demographic changes, so that marine shellfish remained a main source of animal protein. They did not, however, reject the possibility of a population increase, supported by other inland resources, among them agriculture.

On the other hand, Chandler et al. (2005) use alleged dietary differences to demonstrate the existence of two genetically distinctive populations on the basis of the analysis of paleodiets from Lubell et al. (1994). From this study, Chandler et al. concluded that 
the Mesolithic groups had a diet comprising $50 \%$ marine foods, while the Neolithic farming groups had an entirely terrestrial diet (Lubell et al. 1994). This difference in diet demonstrates that the two different settlement patterns observed, that is, the shell middens and the agricultural enclaves, do not represent seasonal movements of a single population, but rather two distinct populations. (Chandler et al. 2005, p. 782)

However, what Lubell et al. actually stated, based on the results from Mesolithic and Neolithic non contemporary samples, is that

The [Mesolithic Neolithic] transition can be described as an abandonment of marine resources in favour of terrestrial ones... We can thus show, for the first time, that the introduction of a Neolithic economy in Portugal was an intensification of a trend which started as an adjustment to problems of food supply during an earlier period of sea level, climatic and vegetational change. (Lubell et al. 1994, p. 214)

Therefore, Lubell et al. (1994, p. 214) tend to support the option of population conti nuity, rather than the opposite.

Furthermore, Zilhão (1998a, pp. 693 696) combined Neolithic data on diet, caries, molars and tibiae to support the population replacement hypothesis, back projecting this data by a statistical regression analysis. Since the Mesolithic data did not fit the regression, the implication for him was that one population did not stem from the other, contra Jackes et al. (1997a) and Lubell et al. (1994). But Zilhão's conclusion is meaningful only if external conditions remained equal over time. Conditions were not equal, however, since at least diet had changed. Therefore, the lack of absolute sameness between Mesolithic and Neolithic groups does not automatically imply population replacement (Lubell et al. 1994; Jackes et al. 1997a).

Data on morphology, genetics and diet is controversial because of its very nature (see, for instance, Evershed (2007) for a review of the ability of molecular archaeology to reconstruct diet, touching on the debate generated by Richards et al. (2003) on an abrupt change in diet at start of the Early Neolithic in Britain). Genetic and morphometric data, in particular, are totally dependent on unknown cultural practices, among which patterns of mating and inhumation are probably fundamental potentially creating genetic trends difficult to interpret in a simple positive/negative way.

\section{Chronological Data}

J. Zilhão, based on his analysis of Early Neolithic ${ }^{14} \mathrm{C}$ dates, proposed that small 'groups of leap frogging sea faring colonists ... moved around the Mediterranean coast' (Chandler et al. 2005, p. 785; see also Zilhão 2001), explicitly against the 'wave of advance' model.

Zilhão (2001, 2003) correctly critiqued the use of ${ }^{14} \mathrm{C}$ dates on charcoal, since they may suffer the 'old wood' effect and blur the picture of the transition. He preferred dates obtained from short lived samples. His analysis concluded that

When calibrated, these results indicate that the Neolithic begins significantly earlier in southern Italy, perhaps as early as $6000 \mathrm{cal} \mathrm{BC}$, but that northward and westward all available dates on short lived diagnostic samples are identical to those for Iberia. (Zilhão 2001, p. 14184)

This work remains the major reference in support of the maritime colonization of the region. 
Zilhão's use of ${ }^{14} \mathrm{C}$ dates merits two observations. First, he rightly points to the problem of the large standard deviations of some of the dates, and dismisses five of them apparently on that basis (another four dates are dismissed as 'unacceptable' for being too young or too old). Yet he does consider dates with large standard deviations (up to 160 and 255 years) (Zilhão 2001, p. 14184).

Secondly, Zilhão does use both short lived samples and charcoal, in particular a charcoal date of $5600 \mathrm{BC}$ (standard deviation being either 290 [GANOP C12] or 380 [GANOP C13] years not specified by the author), and a date on cereal with 160 years standard deviation (KN 51) for Cova de l'Or (Alicante) (Zilhão 2001, pp. 14182 14183), thus stressing the relevance of the coastal southeastern sites in the Early Neolithic, as opposed to other early settlements in Huesca, Cádiz, or Portugal, unlikely regions for a maritime initial settlement of the Peninsula.

The fact is, as has been noted many times, that ${ }^{14} \mathrm{C}$ dates are not straightforward evidence. A major problem for Early Neolithic contexts is that the samples might not be dating what the excavators think they are dating (e.g. Bernabeu et al. 2003 for Mas d'Is; see also Barceló 2008 for a regional analysis of dates in Catalonia; Skeates 2003). The Mediterranean Early Neolithic assemblages seem to have an added difficulty, since there is an apparent sharp fall in the number of dates during the 65005500 cal BC period (Barceló 2008). This could be a taphonomic artifact, and in fact the $8.2 \mathrm{ka}$ event, a climatic fluc tuation consisting in an abrupt decrease in temperatures in the North Atlantic that caused a rapid change to colder and dryer conditions in the entire Mediterranean (Weninger et al. 2006) has been linked to this lack of dates (Berger and Guilaine 2009; Bonsall et al. 2002a, b). It has also been claimed that the $8.2 \mathrm{ka}$ event could have caused a population void in the Iberian Peninsula right before the first Neolithic (Berger and Guilaine 2009; López Sáez et al. 2008; González Sampériz et al. 2009). Interestingly, an apparent absence of Meso lithic remains whether caused by a real reduction in population numbers, or by a change in the settlement pattern (Berger and Guilaine 2009) has been shown in most of the areas in which ex novo Early Neolithic settlements have been found (e.g. McClure et al. 2008, p. 327; Rojo et al. 2008; there are, however, regions in the Iberian Peninsula in which the gap in the dates is not apparent: J. Bernabeu, personal communication).

Whether it is a matter of population or taphonomy, finding continuity in the archaeo logical deposits from the Mesolithic into the Neolithic becomes very difficult. As we see in the Spanish Meseta (Rojo et al. 2008), for instance, people would have re occupied these large areas only as a fully agricultural productive economy was consolidated. This is an important point because supporters of the demic models have often alluded to the lack of continuity in the archaeological deposits as proof of a demic replacement by migration.

Given this situation, the use of ${ }^{14} \mathrm{C}$ dates should be aimed at reducing uncertainties as far as possible, and at establishing comparisons over a range of commensurable data. In order to meet these requirements, we should work with dates that have standard deviations of less than 100 years (e.g. Rojo et al. 2008) and are obtained on short lived samples. Of these, we should target only cereal remains and sheep bones, as the exogenous elements in the area, and then admit only those which are specifically attributed by their excavators and publishers to Early Neolithic contexts (i.e. those variously described as 'Neolítico antiguo', 'Neolítico Antiguo. Doble bisel, cardiales' (i.e. with double bevelled microliths and cardial pottery), 'Neolitico inferiore', 'Neolithic Sites with domestic plant macro remains earlier than c. 5000 BP', 'Early cardial phase', 'Early ceramic', 'Neolític Antic', 'Cardial context', or 'Cardial'). Thus this last condition would exclude debated 'transitional' contexts. (The Ovis aries in Cueva de Nerja (see Table 1) can be considered to belong to a Neolithic context (Aura et al. 2010), since the accuracy of the excavators' attributions and 
Table 1 Early Neolithic ${ }^{14} \mathrm{C}$ dates on short lived samples of domesticates $(\mathrm{SD}<100)$

\begin{tabular}{|c|c|c|c|c|c|c|c|}
\hline Sample & Site & Country & Date BP & SD & Material & Date cal BC & Site \# \\
\hline LTL-202A & Favella & Italy & 6956 & 65 & Grain & $5984-5726$ & 1 \\
\hline LTL-203A & Favella & Italy & 6890 & 50 & Grain & $5887-5673$ & 1 \\
\hline Beta- 47808 & Ripa Tetta & Italy & 6890 & 60 & Hordeum vulgare & $5966-5661$ & 2 \\
\hline OxA-1475 & Coppa Nevigata & Italy & 6880 & 90 & Cereal & $5979-5630$ & 3 \\
\hline OxA-1474 & Coppa Nevigata & Italy & 6850 & 80 & Cereal seeds & $5968-5622$ & 3 \\
\hline Beta-110542 & Arene Candide & Italy & 6830 & 40 & Hordeum & $5791-5638$ & 4 \\
\hline LTL-204A & Favella & Italy & 6793 & 40 & Grain & $5736-5630$ & 1 \\
\hline GrA-25715 & San Sebastiano di Perti & Italy & 6760 & 45 & Cereal & $5732-5575$ & 5 \\
\hline GrA-29403 & Abri Pendimoun & France & 6725 & 45 & Cereal & $5721-5559$ & 6 \\
\hline Beta-223092 & La Paleta & Spain & 6660 & 60 & Charred cereal remains & $5671-5483$ & 7 \\
\hline GrA-29528 & Abri Pendimoun & France & 6650 & 45 & Cereal & $5640-5490$ & 6 \\
\hline Beta-162092 & Mas d'Is & Spain & 6600 & 50 & Hordeum vulgare & $5621-5481$ & 8 \\
\hline Beta-166727 & Mas d'Is & Spain & 6600 & 50 & Hordeum vulgare & $5621-5481$ & 8 \\
\hline Beta-13157 & Cueva de Nerja & Spain & 6590 & 40 & Ovis aries & $5616-5481$ & 9 \\
\hline Beta-239377 & Cendres & Spain & 6510 & 40 & Ovis aries & $5548-5373$ & 11 \\
\hline Beta-221431 & El Barranquet & Spain & 6510 & 50 & Ovis aries & $5607-5367$ & 10 \\
\hline Beta-142289 & La Falguera & Spain & 6510 & 70 & Triticum monococcum & $5614-5328$ & 12 \\
\hline GifA-101360 & Cendres & Spain & 6490 & 90 & Triticum dicoccum & $5617-5310$ & 11 \\
\hline OxA-1853 & San Marco, Gubbio & Italy & 6430 & 80 & Triticum aestivum & $5535-5225$ & 13 \\
\hline OxA-15488 & Can Sadurní & Spain & 6421 & 34 & Triticum dicoccum seed & $5473-5329$ & 14 \\
\hline UBAR-760 & Can Sadurní & Spain & 6405 & 55 & Triticum dicoccum seed & $5481-5299$ & 14 \\
\hline OxA-15489 & Can Sadurní & Spain & 6391 & 34 & Triticum dicoccum seed & $5469-5315$ & 14 \\
\hline OxA-15491 & Can Sadurní & Spain & 6375 & 34 & Triticum dicoccum seed & 5469-5304 & 14 \\
\hline KIA-21356 & La Revilla del Campo & Spain & 6355 & 30 & Domestic ovicaprid & $5466-5228$ & 15 \\
\hline Ly-971 OXA & Kaf Taht el-Ghar & Marocco & 6350 & 85 & Triticum dicoccum & $5483-5076$ & 16 \\
\hline Beta-142288 & Cendres & Spain & 6340 & 70 & Hordeum vulgare & $5478-5081$ & 11 \\
\hline OxA-1035 & Caldeirao & Portugal & 6330 & 80 & Ovis aries & $5476-5076$ & 17 \\
\hline
\end{tabular}


Table 1 continued

\begin{tabular}{|c|c|c|c|c|c|c|c|}
\hline Sample & Site & Country & Date BP & SD & Material & Date cal BC & Site \# \\
\hline Beta-208134 & El Mirador & Spain & 6320 & 50 & Triticum dicoccum & $5467-5212$ & 18 \\
\hline UtC-13347 & La Revilla del Campo & Spain & 6313 & 48 & Cereal & 5466-5209 & 15 \\
\hline Ua36215 & Los Castillejos & Spain & 6310 & 45 & Cereal & 5464-5209 & 20 \\
\hline OxA-10192 & Or & Spain & 6310 & 70 & Triticum aestivum? & $5470-5076$ & 19 \\
\hline Beta-107405 & Cendres & Spain & 6280 & 70 & Ovis aries & $5466-5052$ & 11 \\
\hline UtC-13346 & La Lámpara & Spain & 6280 & 50 & Cereal & $5366-5073$ & 21 \\
\hline OxA-10191 & Or & Spain & 6275 & 70 & Triticum aestivum? & $5465-5047$ & 19 \\
\hline OxA-1851 & San Marco, Gubbio & Italy & 6270 & 70 & Triticum compactum & $5464-5040$ & 13 \\
\hline H-1754 & Or & Spain & 6265 & 75 & Triticum & $5464-5021$ & 19 \\
\hline Ua36214 & Los Castillejos & Spain & 6260 & 45 & Cereal & $5323-5068$ & 20 \\
\hline UtC-13296 & La Revilla del Campo & Spain & 6250 & 50 & Cereal & $5322-5058$ & 15 \\
\hline UtC-13295 & La Revilla del Campo & Spain & 6250 & 50 & Cereal & $5322-5058$ & 15 \\
\hline UtC-13294 & La Revilla del Campo & Spain & 6240 & 50 & Cereal & $5316-5056$ & 15 \\
\hline Ua36212 & Los Castillejos & Spain & 6240 & 45 & Cereal & $5314-5061$ & 20 \\
\hline OxA-1034 & Caldeirao & Portugal & 6230 & 80 & Ovis aries & $5370-4965$ & 17 \\
\hline UtC-13350 & La Revilla del Campo & Spain & 6210 & 60 & Cereal & $5309-5011$ & 15 \\
\hline Beta-295152 & Casa Montero & Spain & 6200 & 40 & Ovis aries & $5296-5046$ & 22 \\
\hline Wk-25171 & Cueva de los Mármoles & Spain & 6198 & 31 & Hordeum vulgare & $5291-5049$ & 23 \\
\hline KIA-21354 & La Revilla del Campo & Spain & 6177 & 31 & Ovicaprid & $5219-5033$ & 15 \\
\hline KIA-21353 & La Revilla del Campo & Spain & 6156 & 33 & Ovicaprid & $5213-5011$ & 15 \\
\hline Ua37835 & Los Castillejos & Spain & 6155 & 45 & Cereal & $5221-4963$ & 20 \\
\hline GrN-6169 & Cueva de los Murciélagos & Spain & 6150 & 45 & Cereal & $5219-4963$ & 24 \\
\hline Beta-208133 & El Mirador & Spain & 6150 & 40 & Triticum & $5216-4991$ & 18 \\
\hline Ua37844 & Los Castillejos & Spain & 6140 & 45 & Cereal & $5215-4961$ & 20 \\
\hline Ua37839 & Los Castillejos & Spain & 6130 & 50 & Cereal & $5216-4940$ & 20 \\
\hline Beta-208132 & El Mirador & Spain & 6120 & 40 & Triticum dicoccum & $5209-4953$ & 18 \\
\hline UtC-13348 & La Revilla del Campo & Spain & 6120 & 60 & Cereal & $5220-4851$ & 15 \\
\hline
\end{tabular}


Table 1 continued

\begin{tabular}{|c|c|c|c|c|c|c|c|}
\hline Sample & Site & Country & Date BP & SD & Material & Date cal BC & Site \# \\
\hline Ua36208 & Los Castillejos & Spain & 6120 & 40 & Cereal & $5209-4953$ & 20 \\
\hline Ua36213 & Los Castillejos & Spain & 6120 & 40 & Cereal & $5209-4953$ & 20 \\
\hline OxA-1854 & San Marco, Gubbio & Italy & 6120 & 90 & Hordeum vulgare & $5298-4838$ & 13 \\
\hline Ua36203 & Los Castillejos & Spain & 6115 & 40 & Cereal & $5209-4945$ & 20 \\
\hline Beta-220914 & El Mirador & Spain & 6110 & 40 & Triticum dicoccum & $5209-4941$ & 18 \\
\hline Beta-197384 & El Mirador & Spain & 6100 & 50 & Triticum diccoccum & $5210-4856$ & 18 \\
\hline Ua36210 & Los Castillejos & Spain & 6100 & 45 & Cereal & $5209-4859$ & 20 \\
\hline Ua37838 & Los Castillejos & Spain & 6095 & 45 & Cereal & $5208-4856$ & 20 \\
\hline Ua36209 & Los Castillejos & Spain & 6090 & 40 & Cereal & $5208-4853$ & 20 \\
\hline Ua37834 & Los Castillejos & Spain & 6085 & 45 & Cereal & $5208-4849$ & 20 \\
\hline Beta-171124 & Barruecos & Spain & 6080 & 40 & Cereal & $5206-4847$ & 25 \\
\hline Ua37837 & Los Castillejos & Spain & 6065 & 50 & Cereal & $5207-4810$ & 20 \\
\hline Hd-15451 & La Draga & Spain & 6060 & 40 & Charred cereal seeds & $5196-4842$ & 26 \\
\hline GrN-6639 & Cueva de los Murciélagos & Spain & 6025 & 45 & Cereal & $5036-4798$ & 24 \\
\hline UBAR-313 & La Draga & Spain & 6010 & 70 & Charred cereal seeds & $5202-4721$ & 26 \\
\hline
\end{tabular}

OxCal v4.1.7 (Bronk Ramsey 2009); IntCal09 atmospheric curve (Reimer et al. 2004); 2-sigma calibration. Based on BANADORA (http //www.archeometrie.mom.fr/banadora/index.php); Catalunya ${ }^{14} \mathrm{C}$ (Base de Dades Radiocarbòniques de Catalunya, http //www.telearchaeology.com/c14/index.htm); Spatial and Chronological Patterns in the Neolithisation of Europe [online database] http // archaeologydataservice.ac.uk/archives/view/c14 meso/index.cfm; Shennan and Steele (2000), Gkiasta et al. (2003), Munoz (1972), Costantini and Stancanelli (1994), Binder and Maggi (2001), Zilhao (2001), Utrilla (2002), Ballouche and Marinval (2003), Stika (2005), Bernabeu et al. (2003, 2009), Zapata et al. (2004), Cerrillo (2005, 2008), Jordá Pardo and Aura (2006), Esquembre et al. (2008), Jiménez (2008), Rojo et al. (2008), van Willigen et al. (2008), Vergés et al. (2008), Alday (2009), Bernabeu and Fumanal (2009), Carvalho et al. (2010), Binder and Sénépart (2010), Martín et al. (2010), Martínez et al. (2010), Natali (2010), Consuegra et al. (in press), Manel Edo (personal communication) 
interpretations is not under scrutiny here, but see Hernando 1999; Barceló 2008 for an account of the mismatch between traditionally accepted chronological spans and Neolithic ceramic assemblages). This ranking of sampling for ${ }^{14} \mathrm{C}$ dates is restrictive (cf Zilhão 2011, p. 47): only 69 dates from 26 sites within the span 70006000 BP meet these criteria. They were gathered from online databases and bibliographical references (see caption, Table 1), and rationalised through a further process of personal communications with Dr. Leonor Peña Chocarro, Dr. Juan Francisco Gibaja Bao, and (for France) Dr. Laurent Bouby.

Some dates have been subject to doubt. For example, Skeates writes:

I have become even more concerned about the poor quality of the samples used to date the Mesolithic Neolithic transition in Italy ... We may even have to start all over again, particularly if we are to talk about the spread of agriculture, using large numbers of AMS determinations on domesticated cereal grains and sheep bones. (Skeates 2003, p. 158)

Coppa Nevigata's dates have been contested for a while (thus: 'Many early dates for fully agricultural sites are no longer accepted, e.g., Coppa Nevigata': Donahue 1992, p. 78, no further detail is given), although Costantini and Stancanelli (1994) and Skeates (2003) accept them. Ripa Tetta has just one date on charred seed kernels (cariossidi di cereali: Tozzi 2002; Costantini and Stancanelli 1994) and the same situation holds for Arene Candide (Binder and Maggi 2001). In fact, I have included all dates obtained from unspecified 'cereal'; they total 35 dates in 11 sites.

Clearly, ${ }^{14} \mathrm{C}$ dates are scarce. They also require an assessment of the contextual evi dence (for instance, Beta 162092 and Beta 166727, in Mas d'Is, come from superimposed deposits, so one or both must be out of place: Bernabeu et al. 2003, pp. 52 53). Likewise, it would be desirable for publications to include information on how the samples were obtained (i.e. in the excavation or in subsequent sieving?) as well as information on what was dated (one sample or an aggregated of samples?). The dates also show a high level of overlap in the standard deviations as the calibration curve (Reimer et al. 2004) is relatively unstable between 6500 and 6000 BP. New dates on short lived samples for the entire Western Mediterranean are evidently needed to advance the debate, especially as ${ }^{14} \mathrm{C}$ dates tend to be used as primary proxies for social and historical processes.

The imbalance of dates among regions is evident (Fig. 2), with the bulk of them located in the Iberian Peninsula. There is also a large imbalance in the distribution of dates by site, but they tend to be consistent internally in terms of their standard deviations. In fact, the whole corpus of dates appears fairly consistent, with no strangely old dates that could cast doubt on the quality of the evidence, or doubts due to statistical uncertainty in the cali bration of the dates. In addition, no taphonomic or contamination processes can be invoked a priori. In this regard, it is important to keep in mind that these dates do not necessarily date archaeological contexts; they represent a set of independent events (the first remains of domesticates in the region). Therefore, we are not necessarily dating the 'Neolithic' (as for instance an ash layer would date an eruption). The argument revolves specifically around when exogenous domestic elements were first being used in certain places.

Figure 3 shows the distribution of dates, approximately as a normal bell curve Gaussian distribution around the average value. In order to assess the statistical similitude/dissi militude between the significant geographical areas in the context of this paper, we compared the oldest date in each group. Considering all dates in each group would have introduced noise into the analysis, since younger dates are always much more abundant because the use of domesticates continued through time. In other words, we calculated the probability that one date is older than another, assuming that their intervals are distributed 


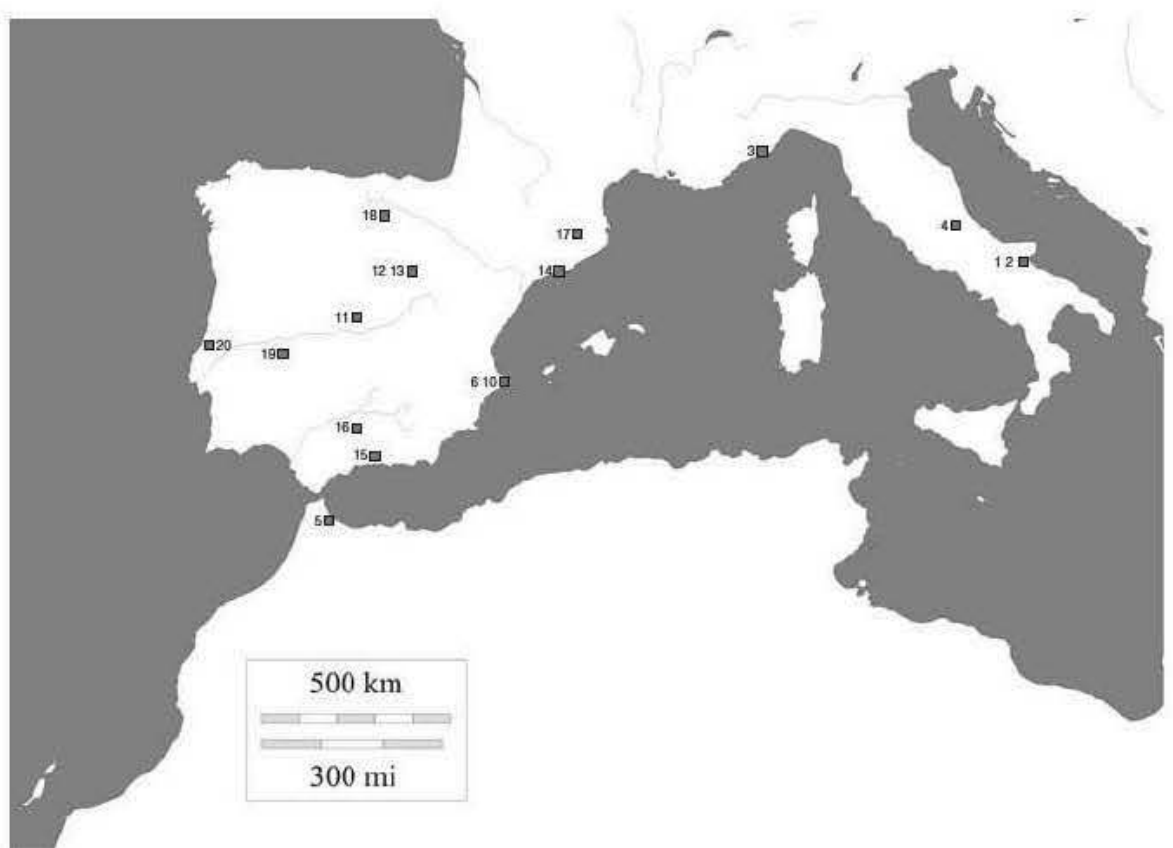

Fig. 2 Western Mediterranean: approximate location of sites with dates analyzed in the text. See Table 1 for site names. (Map base: http://www.education.gouv.fr/)

as a Gaussian too (the statistical analyses were performed by Antonio José Cuesta Vázquez [Yale University], and Jose Manuel Rojo and Almudena Mata Murillo [CCHS, CSIC]. Probability has been calculated through

$$
f(x)=\frac{1}{\sigma \sqrt{ } 2 \pi} e^{\frac{1}{2}\left(\frac{x-\mu}{\sigma}\right)^{2}}, \quad x \in \mathbb{R},
$$

with $\mu$ as the average, and $\sigma$ as standard deviation). The probability that Favella is sig nificantly older than Arene Candide is greater than $90 \%$; the probability that Arene Candide is significantly older than Abri Pendimoun is greater than $80 \%$; the probability that Arene Candide is significantly older than La Paleta is $94.3 \%$; the probability that Arene Candide is significantly older than Mas d'Is is $98.56 \%$.

Within the Iberian Peninsula, a statistical comparison among dates in order to dis criminate a temporal difference between coast and interior appears meaningless, since the oldest currently known ${ }^{14} \mathrm{C}$ dates are from Toledo (La Paleta), in the centre of the Pen insula, and Alicante (Mas d'Is), on the coast. There is no clear argument for dismissing any of the dates at present, despite the fact that the date from La Paleta was obtained from an aggregation of wheat and other palaeobotanic material.

This simple update of the evidence leads to the following remarks:

The Neolithic of southern Italy appears substantially older than the other regional groups. However, this area belongs to a different cultural zone, that of the Adriatic Impressed Ware, which does not appear to be particularly closely related to northwestern Italy, as best represented by the Cardial pottery (van Willigen 2007; see also Improta and Pessina 1998). 
Fig. 3 Calibrated dates, OxCal v4.1.7 (Bronk Ramsey 2009); IntCal09 atmospheric curve (Reimer et al. 2004); 2 sigma calibration. 1. LTL 202A to OxA 1474, 2. Beta 110542 to GrA 29403, 3. Beta 223092.

Notice that Group 2 includes one date from LTL 202A to OxA 1474, and Group 3 includes three dates from Italy

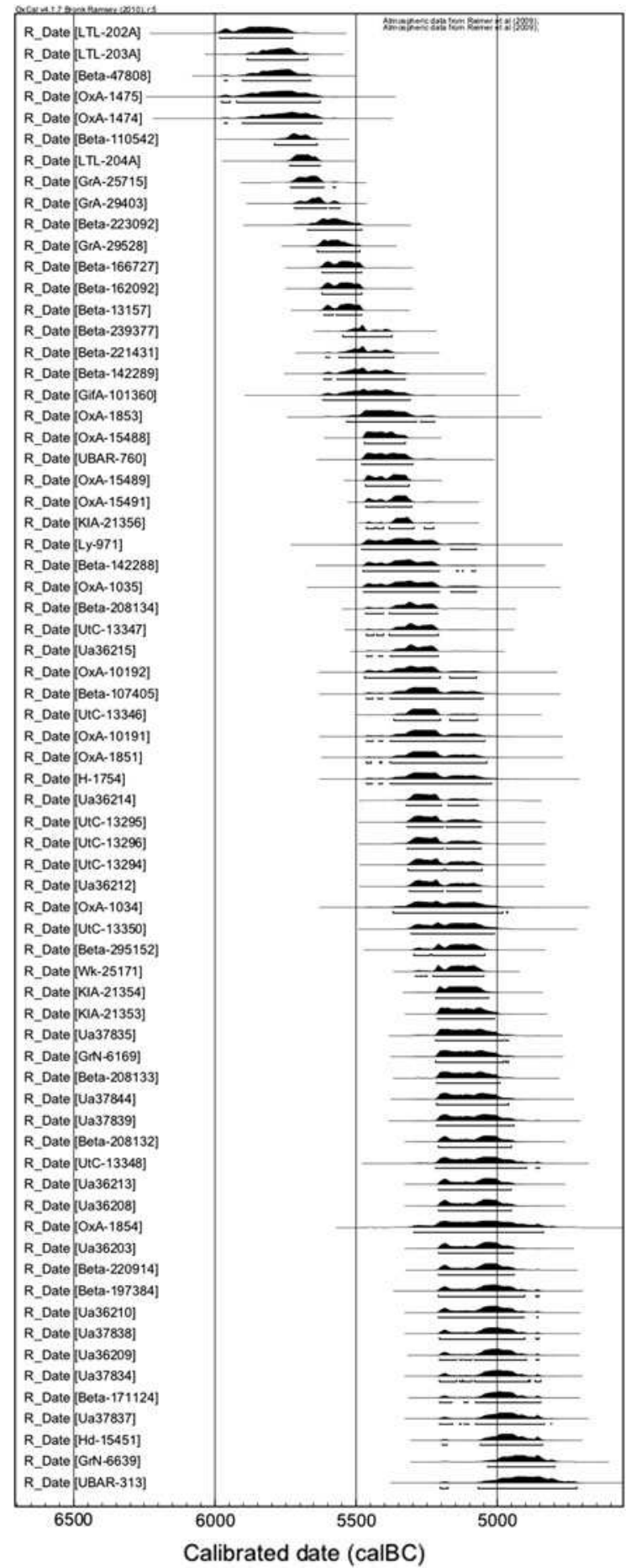


The most widely accepted origin for alleged immigrants from Italy into the Iberian Peninsula is the Italian northwest (Arene Candide), which appears to be geographically and temporally connected with southeastearn France (Abri Pendimoun). Domesticates were in use in this area earlier than in the rest of the Western Mediterranean.

The current gap between these dates and the oldest dates in the Iberian Peninsula is difficult to evaluate. Abri Pendimoun seems to point to a trend of gradual westward expansion of domesticates, but the gap could also translate into a break in the process. In either case, it is difficult to safely establish a direct relationship between the Iberian and the Italian dates, contra the cause effect relationship between the two areas established by the migrationist models. The statistical difference between east and west would contradict the basic assumption of the 'maritime pioneer colonization' model that, as a result of long distance navigation, 'the dates for the first appearance of the Neolithic package are indistinguishable statistically from central Italy to Portugal' (Zilhão 2001, p. 14180). The Neolithisation process in the Western Mediterranean might have proceeded at a much slower pace than was previously acknowledged (see also Manen and Sabatier 2003 for an analysis of ${ }^{14} \mathrm{C}$ dates, also questioning the alleged rapidity of the process throughout the area). Moreover, genetic and material culture evidence do not allow us to establish a direct connection between the two areas, and specifically, a subsidiary relationship of the Iberian Peninsula to Italy, via colonizers (see above).

Secondly, two interesting phenomena occur in the Iberian Peninsula (see also Bernabeu et al. 2009, p. 84). On the one hand, there is a remarkable lack of old dates in Catalonia, which does not show up in this first picture of the Early Neolithic. The problem is not that the Early Neolithic in this region is later than in the rest of the Iberian Peninsula (Morales et al. 2010), but that the dates in Catalonia are not older than in other areas, as would be expected according to migrationist models.

On the other hand, the chronological difference between the dates from coastal and inland sites with traces of agriculture in the Iberian peninsula starts to fade (see also Rojo et al. 2008; Zapata et al. 2004; Stika 2005; Cerrillo 2005, 2008; Jiménez 2008; Alday 2009), and the Neolithic sites in the Spanish plateau are not necessarily found immediately by big rivers. The supporters of the migrationist hypothesis have consistently downplayed the Iberian Early Neolithic inland evidence on the basis of taphonomic arguments. They have implied that the Early Neolithic contexts excavated in the interior areas have prob lems that lead to anomalous early dates dates that, if correct, could subvert the maritime pioneer model. Thus, they have supported the idea of a 'pure' Neolithic on the coast, and a sort of secondary, 'mixed' Neolithic in the interior. The excavators of these early contexts on the interior interestingly enough, themselves supporters of the migrationist models have shown this evidence to be as 'initial' and 'pure' as any other (see Rojo et al. 2008; Jiménez 2008).

\section{On Possibilities}

${ }^{14} \mathrm{C}$ dates and material culture show connections between different regions of the Western Mediterranean in the Early Neolithic, along with a degree of independence in the formation of the Early Neolithic in the Iberian Peninsula. In the absence of clear direct material and chronological cause effect connections, the nexus (that is, migration of people) should be given less prominence in any explanation of the Early Neolithic.

The available record (ceramic variability, no clear spatial logic, possible gradualism together with penecontemporaneity in different parts of the Western Mediterranean a 
region spanning $1,000 \mathrm{~km}$ ) should be explained through other plausible hypotheses. In the Iberian Peninsula it is important to begin by assuming that the so called Early Neolithic does not represent the moment of adoption/arrival of domesticates or an initial 'trial and error' agriculture, but the time period in which productive economy (agriculture) and village life appear, fully consolidated, in the archaeological record, in inland and coastal areas alike (see also García 2010; Bernabeu et al. 2009).

In order to explain this abrupt archaeological transition, Guilaine's (e.g. 2003) work is useful: he hypothesized an arrhythmic phase (phase d'arythmie) in the spread of the Neolithic in certain areas, with a time lag (temps de latence or fermentation), meaning that certain social processes or regional situations actually 'halted' or delayed the spread of the Neolithic in those regions. The Iberian Peninsula and, to a lesser extent, Morocco were probably latence or fermentation areas. In this sense, fermentation would imply that the historical, social and economic processes that constituted the Mesolithic Neolithic tran sition do not find their way into the archaeological record in a straightforward manner. Therefore, the delay in the appearance of Neolithic elements in the archaeological record of the Western Mediterranean might be best read as a time lag (décalage) between real life and the archaeological record, rather than between east and west. This means that complex social processes created a 'filter' between the arrival of the domesticates and their visibility in the archaeological record.

The nature of these complex social processes is of course a matter of debate. A possible avenue for exploration would be how the shifting social life of objects, especially at the transition to food production, would affect the interpretation of the Mesolithic Neolithic boundary. The first domesticates and pottery, charged with high social value, were likely primary objects of 'down the line' exchange among hunter gatherers, in which every group keeps a small part of the goods, passing the rest on to the neighbours or groups with which they keep contact. This possibility was advanced for the Iberian Peninsula by Rodríguez et al. (1995) and Vicent (1997), who emphasized exchange as the underlying process for the spread of the Neolithic package (see also Lewthwaite 1986).

This kind of interaction and exchange would have been slow to find its way into the archaeological record, since a structural shortage of these elements would have been required, in order that they maintain their strategic and prestige value. The effect of this structural shortage of prestige elements would be their virtual invisibility in the archaeo logical record.

New political power related processes, such as a reorganization of exchange networks and accumulation and immobilization of prestige elements, would change this panorama, as observed in the oldest evidence for the Early Neolithic in the Iberian Peninsula. One classic example is Cova de l'Or, an ex novo cave site, for several decades considered the oldest Neolithic site in the Peninsula. It produced an important collection of marine shells (polished and with perforations); polished axes; bone burins (also interpreted as hair pins); rings; needles; stone, shell, and fish vertebrae beads; bracelets; bone palette knives and spoons; small plaques, perforated bones and teeth; a necklace; bird bone flutes; a bird clay figurine impressed with cardium shell; abundant lithic industry with microwear indicative of cereals; and extremely abundant ceramic remains many of them complete vessels richly decorated with cardium shell impressions. One of these was filled with $2 \mathrm{~kg}$ of ochre powder, and cinnabar from a long distance source in the peninsula (García et al. 2006). Domestic sheep and/or goats $(267 \mathrm{MNI})$; pigs ( 72 more than $70 \%$ of these young specimens); dispersed human bones; and an extremely large amount of toasted wheat and barley seeds (Hopf's [1966] two analyzed samples of this deposit found 3,416 seeds of 
three kinds of wheat and 2,176 seeds of two kinds of barley) completed the set (Martí 1977; Martí et al. 1980, 2001).

One more recent example is Can Sadurní, where in Layer 18, six human individuals were found associated with large Cardial jars full of charred cereal seeds, together with depositions of partial and entire Iberian ibex (Capra pyrenaica) remains, bone spoons, rich lithic industry on jasper, and ornaments such as shell bracelets and appliqués. More than 60,000 cereal seeds have been recovered from the site (Manel Edo, personal communi cation; Edo et al. 2011). The site has been interpreted as 'the result of an intentional deposit of grains in pottery vessels that were subsequently burned, perhaps as part of some type of funerary ritual' (Antolín and Buxó 2011, p. 64).

This abundance, variety and degree of elaboration of material culture is rare in the Iberian Peninsula, especially in Later Neolithic sites. It brings to mind two notions: 'structured deposition', advanced for the Early Neolithic elsewhere in Europe (see Pearce 2008); and ‘democratization' (see Gosden and Knowles 2001, p. 203).

It is also possible that collective labour was concentrated in particular endeavours. In Mas d'Is (Penàguila, Alicante) two sections of concentric circular ditches around a village have been excavated. They date back to $54505150 \mathrm{cal} \mathrm{BC}$, and represent 180,000 225,000 person hours (Bernabeu et al. 2003, p. 55). This case stands in remarkable contrast to the rest of the Iberian Neolithic and Mesolithic archaeological record, but if the calculation of both labour and resources is accepted, this probably represents a turning point in social organization, involving a different power structure, although probably not yet characterisable as a truly peasant society. The transition, in any case, implies a shift from archaeological invisibility to visibility.

One way to understand this process is through the Peer Polity Interaction model (Renfrew 1982), advanced to explain the transition to state organisation in a maritime environment: inland groups would interact with neighbouring groups forming an over lapping network of relationships that was inserted into a pre existing social formation. Groups in both cases are units that interact in the same geographical setting and evolve together (Renfrew 1982, p. 287).

The key point in our context is that groups need 'cooperation', in the sense that the changes tending to increase work investment and reorganize social relations are legitimised by the existence of comparable processes in neighbouring units (Renfrew 1982, p. 289). The combination of changes in production, exchange, and accumulation of work and goods leads to a self organizing or emergent process (about this term, see McGlade 1999) reinforced through interaction. In short, peer groups are not able to achieve transitions in isolation (Renfrew 1982, p. 287; see also Price 1977). This is equally applicable (explicitly so in Price's cluster interaction model) to any kind of social formation that involves the existence of interdependent polities.

In the case of the Iberian Peninsula, polities were probably groups articulated through a complex network of sustained interaction and exchange. In the Early Neolithic, it can be inferred that exchange shifted into a pattern of selective deposition, reinforced by support among social and political entities involving the entire social formation.

In this account, new social practices within groups, reinforced by horizontal relation ships among them, are emphasized, while horizontal transmission of objects and indi viduals is downplayed.

The archaeological record resulting from this situation would, interestingly, lack a clear geographical pattern in its manifestation. All relevant material elements linked to the process are logically associated, and the presence of any of them is a product of the presence of all the others. Previously invisible nodes would emerge, concentrating 
previously circulating work and resources. In short, this process would generate an archaeological record akin to the one observed in the Iberian Peninsula during the Early Neolithic: similar material culture and practices showing up in the record penecontem poraneously in apparently disconnected places and heterogeneous locations: mountainous areas, plateaus; coastal, riverine or interior areas; open air, cave, and rock shelters.

Evidence of agriculture and use of domestic animals in Mesolithic contexts is prob lematic (Zapata et al. 2004), likely due to less intense research on this aspect, among other issues. But the evidence is growing, as much more attention is devoted to the subject of early agriculture and its development (Stika 2005; Peña Chocarro et al. 2005; Buxo 2007; Peña Chocarro 2007; Zapata Peña 2007), and areas previously deemed unlikely locations for early agriculture are being included in the picture (northern Portugal, the Ebro valley, and the central plateau). The same is true for exchange networks, which nonetheless begin to be attested for the Mesolithic Early Neolithic boundary: Mediterranean shells (Pallarés et al. 1997); various lithic and mineral products such as flint (García 2009, p. 95), cinnabar (Hunt Ortiz et al. 2011), or schist and sillimanite (Orozco 2000); a complete catalogue of these interactions and exchange networks is forthcoming (in Xàrxes al Neolitic, Interna tional Conference 2011); see also Convertini (2010) for exogenous pottery, and Fernández et al. (2006) for continuing interaction in the Mediterranean basin through goat mtDNA. The existence of relatively large scale exchange networks, in place from the first moments of the Early Neolithic, is difficult to explain among newly settled communities, alien to the territory.

This is only a tentative approach that needs much more elaboration and evidence. In particular, it would not be acceptable to just replace 'migrations' with undefined 'exchange'. This needs qualification. But this proposal is not far from Watkins's (2008) proposal for the early Neolithic in southwest Asia, that he hypothesizes as the (archaeo logical) emergence of basic peer polities Early Neolithic societies emphasizing the networks operating among them in previous periods. In the Iberian Peninsula, Oosterbeek (2001) has also highlighted the political character of the Neolithic transition, paying attention to regional variability within a shared path to social complexity, intentional or forced.

In any case, as research progresses the picture gets more and more complex, and transitional and mixed situations start to appear in the record. The unitary vision of a formative phase fades, and ${ }^{14} \mathrm{C}$ dates will increasingly complicate things as they contribute to the deconstruction of a migratory coastal scenario (Díaz del Río 2010).

\section{On Plausibility}

The current state of archaeological positive evidence makes internal consistency and plausibility very relevant factors in the debate. Inconsistencies are independent of any kind of contrary evidence.

Alternative proposals to migration have shortcomings, as they may generate the need for 'invisible' archaeological processes; may be partially based on negative evidence; or require a still unspecified degree of time depth (contra the 'maritime pioneer colonization' model). But time, probably the most debatable issue, could actually account for the rela tively high degree of regional variability in material culture, and the lack of clear original sources for the pottery types found in the Iberian Peninsula. In any case, more ${ }^{14} \mathrm{C}$ dates on short lived samples, and research directed towards narrowing the gap that currently exists between the Mesolithic and the Early Neolithic in the peninsula, are clearly needed. 
On the other hand, criticisms of the plausibility of the paradigmatic model have inev itably arisen (e.g. Zapata et al. 2004). Its lack of soundness in explaining certain kinds of archaeological data, such as pottery (e.g. Guilaine 2003, p. 195; and see above), has been highlighted. I will just point here to the question, lying at the heart of the 'maritime pioneer colonization' model, of why people migrate. Zilhão has proposed that the settlers arrived on the Peninsula after breaking from their original groups in the Eastern Mediterranean. The pattern he sees involved groups splitting, rather than becoming so large that conflict and inequality arose:

Along the north Mediterranean shores, this tendency to fission and move on would have been reinforced further because opportunities for settlement and expansion around initial enclaves were limited by physical geography and the presence of local hunter gatherer groups. (Zilhão 2001, p. 14185)

Further, Zilhão links the Mediterranean expansion to a tradition extending right back to the collapse of PPNB in Anatolia. Thus:

agriculture may have been brought to Europe by pioneers escaping from dominance in ranked societies and striving to maintain egalitarianism through the application of strict controls to group size. (Zilhão 2003, p. 219)

From the opposite viewpoint, that of the well adapted Iberian hunter gatherers, Zilhão asks what attraction herding and farming could possibly have had. In relation to Medi terranean Iberia and Portugal, he argues that it is 'indisputable' that they had no good reason for adopting a Neolithic economy, and that the empirical evidence indicates that they indeed did not do so:

Far from pushing hunter gatherers into the negligible role of passive participants, this view implies the exact opposite: that they had a very active participation in the process indeed, but one of active rejection, not active acceptance of the Neolithic package. How else can we explain the survival in the estuaries of the Tagus and the Sado, for several centuries after pottery and sheep are first documented in the caves and rock shelters of the adjacent limestone massifs, of societies that were fully Mesolithic in their material culture and fully forager in their economy? (Zilhão 2011, p. 62)

This kind of statement is difficult to argue against. However, the Neolithic should probably not be regarded as an intentional decision on the part of would be agriculturalists, so some of the questions posed by Zilhão are simply inapposite. Thus, the last question could be posed in precisely opposite terms: why should people move at all? It runs precisely against most archaeological and anthropological thinking to suppose that small groups of humans would launch themselves into a process of highly uncertain maritime colonization in order to avoid conflicts that were yet to come. In particular, the Italian Neolithic record does not support the existence of an exceedingly large population, able to colonize not only coastal areas, but also deep inland regions. Moreover, there is no trace of resistance or conflict in the Early Neolithic record of the Western Mediterranean. And if Early Neolithic settlers were absorbed by the Mesolithic population (Chandler et al. 2005), it is not clear why they should go on with the colonization process. Newly accultured groups moving along the coast would have taken much longer to reach Portugal than the 'maritime pioneer colonization' model allows. Finally, there is no explanation for the fact that alleged colonizers stopped in central Portugal, settled in inland places rather than coastal locations, and did not choose the same kind of locations everywhere, since 
migrationist assumptions dictate that places would be chosen due to the presence of par ticular characteristics.

\section{Beyond Rates of Spread}

As the archaeological picture has increased in complexity in recent years, mostly in terms of the ceramic evidence, the principal response of researchers has been to populate the paradigmatic model with more 'actors', and more pathways of penetration and contact between the extremes of the Western Mediterranean from southern Italy through North Africa, and through the northern Mediterranean via France as well as to acknowledge that pioneer colonization took place both on the coast and in the interior (e.g. Bernabeu et al. 2003; Manen et al. 2007; McClure et al. 2008; Bernabeu and Molina 2009).

Since the evidence does not directly corroborate migrationist models, other hypotheses can be advanced that reach acceptable levels of plausibility. Our challenge is, in a sense, in acknowledging the potential effect of expanded maritime contacts during the Neolithic (Broodbank 2006; Robb 2007; but see Alcover 2008 and Ramis 2010 for late colonization of the Balearic Islands), without simply taking the fact of such contacts as the entire explanation for the Neolithic.

The complex archaeological record that confronts us for the Early Neolithic of the Iberian Peninsula requires us to imagine complex social and historical processes, which do not necessarily show up in a straightforward manner in the record. This may disqualify it as a means to map out the spatial and chronological progression ("jalonner la progression spatiale et chronologique': Guilaine 2003, p. 199) of the different Neolithic materials, showing a neat and orderly expansion of elements. Of course, at a pan Mediterranean scale, the progression of the arrival of domesticates from the Levant cannot be questioned. There is a delay in the appearance of domestic elements in the record, from the Eastern Mediterranean into the Western Mediterranean, due to the 'larger than life' spatial and temporal scales involved (Hazelwood and Steele 2004; see also Bocquet Appel et al. 2009). But this general pattern must not mislead us into attempting to identify it within much smaller regional and local settings, where an archaeology of 'rates of spread' starts to become questionable (see Hazelwood and Steele 2004; Guilaine and Manen 2007). Its underlying assumption is that ${ }^{14} \mathrm{C}$ dates must be interpreted as proxies to qualify the rapidity of expansion of a given phenomenon. Therefore, the archaeological record is used as an alleged mirror of life.

New models, integrating a theory of history with a theory of the formation of the archaeological record, are required to address this issue. Consideration of how the record is constituted; of its apparently paradoxical nature (the way in which rapid changes in the record might be a product of very long term processes); and of whether we can always use it to measure the travel speed of things at all scales, are relevant. In particular, in this context, an archaeology of the origins of the Western Mediterranean/Iberian Early Neo lithic (of the first settlement, the first people, the first agricultural enclaves) (e.g. Gamble et al. 2005), in short, an archaeology of migrations as particular historical phenomena, might represent a question with no answer.

Acknowledgments Thanks to Dolores Segura Buitrago for her interpretive guidance on the genetic data. My warmest thanks and acknowledgement go to Antonio José Cuesta Vázquez for his guidance with the statistical analysis, and to Jose Manuel Rojo Abuin and Almudena Mata Murillo (CCHS, CSIC). Special thanks to Susana Consuegra, Pedro Díaz del Río, Juan Francisco Gibaja Bao, Maribel Martínez Navarrete, 
Sandra Montón and Juan Vicent García, who generously gave me their time and ideas and who really greatly improved the paper. Joan Bernabeu Aubán, Laurent Bouby, Juan Antonio Cámara Serrano, Margaret Conkey, Manuel Edo Benaiges, Antonio Gilman, Marcos Llobera, Araceli Martín Cólliga, Ignacio Montero Ruiz, Susana Pascual, Leonor Peña Chocarro, Damià Ramis, Beatriz Robledo, and Josep Maria Vergès Bosch, were also generous with their comments and bibliographical guidance. Two reviewers of a previous version of this manuscript made constructive suggestions. Marilyn Reynolds and Bruce Harris kindly revised the English. Any error remains my own.

\section{References}

Achilli, A., Rengo, C., Magri, C., Battaglia, V., Olivieri, A., Scozzari, R., et al. (2004). The molecular dissection of mtDNA haplogroup $\mathrm{H}$ confirms that the Franco Cantabrian glacial refuge was a major source for the European gene pool. American Journal of Human Genetics, 75, 910918.

Addison, D. J., \& Matisoo Smith, E. (2010). Rethinking polynesians origins: A west polynesia triple I model. Archaeology in Oceania, 45(1), 112.

Alcover, J. A. (2008). The first Mallorcans: Prehistoric colonization in the Western Mediterranean. Journal of World Prehistory, 21, 1984.

Alday, A. (2009). El final del Mesolítico y los inicios del Neolítico en la Península Ibérica: Cronología y fases. Munibe, 60, 157173.

Ammerman, A. J., \& Cavalli Sforza, L. L. (1984). The Neolithic transition and the genetics of populations in Europe. Princeton: Princeton University Press.

Antolín, F., \& Buxó, R. (2011). Proposal for the systematic description and taphonomic study of carbonized cereal grain assemblages: A case study of an Early Neolithic funerary context in the cave of Can Sadurní (Begues, Barcelona province, Spain). Vegetation History and Archaeobotany, 20, 5366.

Araújo, A. C. (1998). O concheiro de Toledo (Lourinhã) no quadro das adaptações humanas do Pós Glaciar no litoral da Estremadura. Revista Portuguesa de Arqueologia, 1(2), 1938.

Aura, J. E., Pérez Ripoll, M., Jordá Pardo, J. F., García Borja, P., Morales Pérez, J. V., García Puchol, O., et al. (2010). Sobre la transición al Neolítico: Las excavaciones Jordá de la Cueva de Nerja (Málaga, España). In J. F. Gibaja \& A. F. Carvalho (Eds.), Os últimos caçadores recolectores e as primeiras comunidades productoras do sul da Península Ibérica e do norte de Marrocos (pp. 221228 ). Promontoria Monográfica 15. Faro: Universidade do Algarve.

Ballouche, A., \& Marinval, P. (2003). Données palynologiques et carpologiques sur la domestication des plantes et l'agriculture dans le néolithique ancien du Maroc Septentrional (site de Kaf That El Ghar). Revue d'Archéométrie, 27, 4954.

Bar Yosef, O., \& Belfer Cohen, A. (1992). From foraging to farming in the Mediterranean Levant. In A. B. Gebauer \& T. D. Price (Eds.), The transition to agriculture (pp. 21 48). Ann Arbor: International Monographs in Prehistory.

Barceló, J. (2008). La seqüència crono cultural de la prehistòria catalana: Anàlisi estadística de les datacions radiomètriques de l'inici de l'holocè a la edat del ferro. Cypsela, 17.

Belle, E., Landry, P. A., \& Barbujani, G. (2006). Origins and evolution of the Europeans' genome: Evidence from multiple microsatellite loci. Proceedings of the Royal Society of Biological Sciences, 273, 15951602.

Berger, J. F., \& Guilaine, J. (2009). The 8200 cal BP abrupt environmental change and the Neolithic transition: A Mediterranean perspective. Quaternary International, 200, 3149.

Bernabeu, J. (2002). The social and symbolic context of Neolithisation. Saguntum PLAV Extra, 5, 209233.

Bernabeu, J. (2006). Una visión actual sobre el origen y difusión del neolítico en la Península Ibérica. Ca. 56005000 cal. a.C. In El abric de La Falguera (Alcoi, Alacant): 8000 años de ocupación humana en la cabecera del rió de Alcoi (pp. 189 211). Alicante: Diputación Provincial.

Bernabeu, J., Aura, J., \& Badal, E. (1993). Al oeste del Edén: Las primeras sociedades agrícolas en la Europa mediterránea, Historia Universal Prehistoria 4, Síntesis, Madrid.

Bernabeu, J., Barton, C. M., \& Pérez, M. (2001). A taphonomic perspective on Neolithic beginnings: Theory, interpretation, and empirical data in the Western Mediterranean. Journal of Archaeological Science, 28, 597612.

Bernabeu, J., \& Fumanal, M. P. (2009). La excavación, estratigrafía y dataciones ${ }^{14}$ C. In J. Bernabeu \& L. Molina (Eds.), La Cova de les Cendres (Moraira Teulada, Alicante) (pp. 31 52). Alicante: Museo Arqueológico de Alicante.

Bernabeu, J., \& Molina, L. (2009). La Cova de les Cendres: Valoración final. In J. Bernabeu, \& L. Molina (Eds.), La Cova de les Cendres (Moraira Teulada, Alicante) (pp. 195 208). Alicante: Museo Ar queológico de Alicante. 
Bernabeu, J., Molina, L., Esquembre, M. A., Ortega, J. R., \& Boronat, J. (2009). ¿La cerámica impresa mediterránea en el origen del Neolítico de la península Ibérica? In De Méditerranée et d'ailleurs... Mélanges offerts à Jean Guilaine. Toulouse: Archives d'Écologie Préhistorique.

Bernabeu, J., Orozco, T., Díez, A., Gómez, M., \& Molina, F. (2003). Mas d'Is (Penàguila, Alicante): Aldeas y recintos monumentales del Neolítico inicial en el valle del Serpis. Trabajos de Prehistoria, 60(2), 3959.

Bernabeu, J., Pérez, M., \& Martínez, R. (1999). Huesos, neolitización y contextos arqueológicos aparentes. Saguntum PLAV Extra, 2, 589596.

Binder, D., \& Maggi, R. (2001). Le Néolithique ancien de l'arc liguro provençal. Bulletin de la Société préhistorique française, 98(3), 411422.

Binder, D., \& Sénépart, I. (2010). La séquence de l'Impresso Cardial de l'abri Pendimoun et l'évolution des assemblages céramiques en Provence. In C. Manen, F. Convertini, D. Binder, \& I. Sénépart (Eds.), Premières sociétés paysannes de Méditerranée occidentale: Structures des productions céramiques (pp. 149 167). Mémoire LI. Paris: Société Préhistorique Française.

Bocquet Appel, J. P. (2002). Paleoanthropological traces of a Neolithic demographic transition. Current Anthropology, 43(4), 637650.

Bocquet Appel, J. P., \& de Miguel, M. P. (2002). Demografía de la difusión neolítica en Europa y los datos paleoantropológicos. Saguntum Extra, 5, 2342.

Bocquet Appel, J. P., \& Naji, S. (2006). Testing the hypothesis of a worldwide Neolithic demographic transition. Current Anthropology, 47, 341365.

Bocquet Appel, J. P., Naji, S., Vander Linden, M., \& Kozlowski, J. (2009). Detection of diffusion and contact zones of early farming in Europe from the space time distribution of ${ }^{14} \mathrm{C}$ dates. Journal of Archaeological Science, 36(2009), 807820.

Bogucki, P. (1996). The spread of early farming in Europe. American Scientist, 84, 242253.

Bonsall, C., Macklin, M. G., Anderson, D. E., \& Payton, R. W. (2002a). Climate change and the adoption of agriculture in North West Europe. European Journal of Archaeology, 5(1), 923.

Bonsall, C., Macklin, M. G., Payton, R. W., \& Boroneanţ, A. (2002b). Climate, floods and river gods: Envi ronmental change and the Meso Neolithic transition in southeast Europe. Before Farming, 3 4(2), 112.

Boyle, K., \& Renfrew, C. (Eds.). (2000). Archaeogenetics: DNA and the population prehistory of Europe. Cambridge: McDonald Institute for Archaeological Research.

Bronk Ramsey, C. (2009). Bayesian analysis of radiocarbon dates. Radiocarbon, 51(1), 337360

Broodbank, C. (2006). The origins and early development of Mediterranean maritime activity. Journal of Mediterranean Archaeology, 19(2), 199230.

Buxo, R. (2007). Crop evolution: New evidence from the Neolithic of west Mediterranean Europe. In S. Colledge \& J. Conolly (Eds.), The origins and spread of domestic plants in Southwest Asia and Europe (pp. 155 171). Walnut Creek: Left Coast Press.

Carvalho, A. (2010). Le passage vers l'Atlantique: Le processus de néolithisation en Algarve (sud du Portugal). L'Anthropologie, 114, 141178.

Carvalho, A., Peña Chocarro, L., \& Gibaja, J. F. (2010). Datación directa de cebada (Hordeum vulgare L.) de la Cueva de los Mármoles (Córdoba, España). In J. F. Gibaja \& A. F. Carvalho (Eds.), Os Últimos Caçadores Recolectores e as Primeiras Comunidades Productoras do Sul da Península Ibérica e do Norte de Marrocos (pp. 247 249). Promontoria Monográfica 15, Universidade do Algarve, Faro.

Cerrillo, E. (2005). Los Primeros Grupos Neolíticos de la Cuenca Extremeña del Tajo. BAR International Series 1393, Oxford.

Cerrillo, E. (2008). From 'inland Neolithic' to 'Neolithic dwelling in the inland': The role of homogeneous and heterogeneous elements in the explanation of earlier agricultural stages in Central Spain. In M. Diniz (Ed.), Proceedings of the XV World Congress UISPP (Lisbon, 49 September 2006) 18 the Early Neolithic in the Iberian Peninsula (pp. 19 27). Regional and Transregional Components, BAR S1857, Oxbow, Oxford.

Chandler, H., Sykes, B., \& Zilhão, J. (2005). Using ancient DNA to examine genetic continuity at the Mesolithic Neolithic transition in Portugal. In P. Arias, R. Ontañón, \& C. García Moncó (Eds.), Actas del III Congreso del Neolíitico en la Península Ibérica (Vol. 1, pp. 781 786), Monografías del Instituto Internacional de Investigaciones Prehistóricas de Cantabria, Santander.

Chikhi, L., Nichols, R., Barbujani, G., \& Beaumont, M. (2002). Y genetic data support the Neolithic demic diffusion model. Proceedings of the National Academy of Sciences, 99(17), 1100811013.

Cohen, M. N. (2009). Rethinking the origins of agriculture. Current Anthropology, 50(5), 591595.

Consuegra, S., Díaz del Río, P., Capote, M., Castañeda, N., Criado, C., Casas, C., et al. (in press). Casa Montero. An early Neolithic flint mine in Iberia (5300 5200 BC). In J. Lech, \& A. Saville (Eds.), Prehistoric flint mines in Europe. Archaeologia Polona. Institute of Archaeology and Ethnology, Polish Academy of Sciences. 
Convertini, F. (2010). Bilan des études réalisées sur la provenance de la céramique du Néolithique ancien en Méditerranée nord occidentale: Mise au point d'un protocole analytique. In C. Manen, F. Convertini, D. Binder, \& I. Sénépart (Eds.), Premières sociétés paysannes de Méditerranée occidentale: Structures des productions céramiques (pp. 13 27). Mémoire LI. Paris: Société préhistorique française.

Costantini, L., \& Stancanelli, M. (1994). La preistoria agricola dell'Italia centro meridionale: Il contributo delle indagini archeobotaniche. Origini, 18, 149244.

Currat, M., \& Excoffier, L. (2005). The effect of the Neolithic expansion on European molecular diversity. Proceedings of the Royal Society of Biological Sciences, 272, 679688.

Díaz del Río, P. (2010). The Neolithic Argonauts of the Western Mediterranean and other underdetermined hypotheses of colonial encounters. In D. Bolender(Ed.), Eventful archaeologies: New approaches to social transformation in the archaeological record (pp. 88 99). Albany: State University of New York Press.

Donahue, R. E. (1992). Desperately seeking Ceres: A critical examination of current models for the transition to agriculture in Mediterranean Europe. In A. B. Gebauer \& T. D. Price (Eds.), Transitions to agri culture in prehistory, monographs in world archaeology (Vol. 4, pp. 73 80). Madison: Prehistory Press.

Duarte, C. (1998). Necrópole neolítica do Algar do Bom Santo: Contexto cronológico e espaço funerário. Revista Portuguesa de Arqueologia, 1(2), 107118.

Dupanloup, I., Bertorelle, G., Chikhi, L., \& Barbujani, G. (2004). Estimating the impact of prehistoric admixture on the genome of Europeans. Molecular Biology and Evolution, 21(7), 13611372.

Edo, M., Blasco, A., \& Villalba, M. J. (2011). La cova de Can Sadurní, guió sintètic de la prehistòria de Garraf. In A. Blasco, M. Edo, \& M. J. Villalba (Eds.), La cova de Can Sadurní i la prehistòria de Garraf. Actas de las Jornadas Internacionales de Prehistoria 30 anys d'investigació arqueològica a Garraf. Edar, Milan.

Esquembre, M., Boronat, J., Jover, F., Molina, F., Luján, A., Fernández, J., et al. (2008). El yacimiento neolítico del Barranquet de Oliva (Valencia). In M. Hernández, J. Soler, \& J. López (Eds.), Actas del IV Congreso del Neolítico Peninsular II (pp. 183 190). Alicante: Museo Arqueológico de Alicante.

Evershed, R. P. (2007). Exploiting molecular and isotopic signals at the Mesolithic Neolithic transition. Proceedings of the British Academy, 144, 141164.

Fernández, E., Gamba, C., Turbón, D., \& Arroyo, E. (2010). ADN antiguo de yacimientos neolíticos de la Cuenca Mediterránea: La transición al Neolítico desde una perspectiva genética. In J. F. Gibaja \& A. Carvalho (Eds.), Os últimos caçadores recolectores e as primeiras comunidades produtoras do sul da Península Ibérica e do norte de Marrocos (pp. 205 212). Promontoria Monográfica 15, Universidade do Algarve, Faro.

Fortea, F. J. (1973). Los complejos microlaminares y geométricos del Epipaleolítico Mediterráneo español, Memorias del Seminario de Prehistoria y Arqueología, Salamanca.

Galeta, P., Sládek, V., Sosna, D., \& Bruzek, J. (2011). Modeling Neolithic dispersal in Central Europe: Demographic implications. American Journal of Physical Anthropology, 146, 104115.

Gamba, C., Fernández, E., Tirado, M., Deguilloux, M. F., Pemonge, M. H., Utrilla, P., et al. (2011). Ancient DNA from an Early Neolithic Iberian population supports a pioneer colonization by first farmers. Molecular Ecology, 21(1), 4556.

Gamble, C., Davies, W., Pettitt, P., Hazelwood, L., \& Richards, M. (2005). The archaeological and genetic foundations of the European population during the Late Glacial: Implications for 'agricultural think ing'. Cambridge Archaeological Journal, 15(2), 193223.

García, O. (2009). La piedra tallada del Neolítico en Cendres. In J. Bernabeu \& L. Molina (Eds.), La Cova de les Cendres (Moraira Teulada, Alicante) (pp. 85 104). Alicante: Museo Arqueológico de Alicante.

García, G. (2010). Las comarcas centromeridionales valencianas en el contexto de la Neolitización de la fachada noroccidental del Mediterráneo. Trabajos de Prehistoria, 67(1), 3758.

García, P., Domingo, I., \& Roldán, C. (2006). Nuevos datos sobre el uso de materia colorante durante el Neolítico Antiguo en las comarcas centrales valencianas. Saguntum, 38, 4960.

Gignoux, C. R., Henn, B. M., \& Mountain, J. L. (2011). Rapid, global demographic expansions after the origins of agriculture. Proceedings of the National Academy of Sciences, 108(15), 60446049.

Gkiasta, M., Russell, T., Shennan, S., \& Steele, J. (2003). Neolithic transition in Europe: The radiocarbon record revisited. Antiquity, 77(295), 4562.

González Sampériz, P., Utrilla, P., Mazo, C., Valero Garcés, B., Sopena, M. C., Morellón, M., et al. (2009). Patterns of human occupation during the early Holocene in the Central Ebro Basin (NE Spain) in response to the 8.2 ka climatic event. Quaternary Research, 71, 121132.

Gosden, C., \& Knowles, C. (2001). Collecting colonialism: Material culture and colonial change. Oxford: Berg.

Guilaine, J. (2003). Aspects de la néolithisation en Méditerranée et en France. In A. Ammerman \& P. Biagi (Eds.), The widening harvest. The Neolithic transition in Europe: Looking back, looking forward (pp. 189 206). Colloquia and conference papers 6. Boston: Archaeological Institute of America. 
Guilaine, J., \& Manen, C. (2007). Du Mésolithique au Néolithique en Méditerranée de l'Ouest: Aspects culturels. In J. Guilaine, C. Manen, J. D. Vigne, et al. (Eds.), Pont du Roque Haute: Nouveaux regards sur la Néolithisation de la France Méditerranéenne (pp. 303 322). Centre de Recherche sur la Pré histoire et la Protohistoire de la Méditerranée, Toulouse.

Guilaine, J., Manen, C., \& Vigne, J. D. (2007). Pont de Roque Haute: Nouveaux regards sur la néolithi sation de la France méditerranéenne. Toulouse: Centre de Recherche sur la Préhistoire et la Proto histoire de la Méditerranée.

Haak, W., Balanovsky, O., Sánchez, J. J., Koshel, S., Zaporozhchenko, V., Adler, C., et al. (2010). Ancient DNA from European Early Neolithic farmers reveals their near Eastern affinities. PLoS Biology, 8(11), 116.

Haak, W., Forster, P., Bramanti, B., Matsumura, S., Brandt, G., Tänzer, M., et al. (2005). Ancient DNA from the first European farmers in 7500 year old Neolithic sites. Science, 310, 10161018.

Haberle, S. (2003). The emergence of an agricultural landscape in the highlands of New Guinea. Archae ology in Oceania, 38, 149158

Hazelwood, L., \& Steele, J. (2004). Spatial dynamics of human dispersals: Constraints on modelling and archaeological validation. Journal of Archaeological Science, 31, 669679.

Hernando, A. (1999). Los primeros agricultores de la Península Ibérica. Arqueología Prehistórica 2, Sín tesis, Madrid.

Horden, P., \& Purcell, N. (2000). The corrupting sea: A study of Mediterranean history. Oxford: Blackwell.

Hunt Ortiz, M. A., Consuegra Rodriguez, S., Díaz del Río Español, P., Hurtado Pérez, V., \& Montero Ruiz, I. (2011). Neolithic and Chalcolithic VI to III millennia BC use of cinnabar ( $\mathrm{HgS})$ in the Iberian Peninsula: Analytical identification and lead isotope data for an early mineral exploitation of the Almadén (Ciudad Real, Spain) mining district. In J. Ortiz, O. Puche, I. Rábano, \& L. Mazadiego (Eds.), History of research in mineral resources. Cuadernos del Museo Geominero, 13. Madrid: Instituto Geológico y Minero de España.

Improta, S., \& Pessina, A. (1998). La neolitizzazione dell'Italia settentrionale: Il nuovo quadro cronologico. In Pessina, A., \& Muscio, G. (Eds.), Settemila anni fa il primo pane: Ambienti e culture delle società neolitiche. Catalogo della Mostra, dicembre 1998 maggio 1999 (pp. 107 115). Udine: Museo friulano di storia naturale.

Jackes, M., Lubell, C., \& Meiklejohn, C. (1997a). On physical anthropological aspects of the Mesolithic Neolithic transition in the Iberian Peninsula. Current Anthropology, 38, 839846.

Jackes, M., Lubell, C., \& Meiklejohn, C. (1997b). Healthy but mortal: Human biology and the first farmers of western Europe. Antiquity, 71, 639658.

Jiménez, J. (2008). El horizonte cardial del interior de la Península Ibérica. In M. Hernández, J. Soler, \& J. López (Eds.), Actas del IV Congreso del Neolitico Peninsular II (pp. 348 355). Alicante: Museo Arqueológico de Alicante.

Jordá Pardo, J. F., \& Aura, J. (2006). Radiocarbono, cronoestratigrafía y episodios ocupacionales en el Pleistoceno superior y Holoceno de la Cueva de Nerja (Málaga, Andalucía, España). In J. Maillo, \& E. Baquedano (Eds.), Miscelánea en homenaje a Victoria Cabrera. Zona Arqueológica 7(I), Madrid, pp. 578597.

Karafet, T., Mendez, F., Meilerman, M., Underhill, P., Zegura, S., \& Hammer, M. (2008). New binary polymorphisms reshape and increase resolution of the human Y chromosomal haplogroup tree. Gen ome Research, 18, 830838.

Keeley, L. H. (1992). The introduction of agriculture to the western North European Plain. In A. B. Gebauer, \& T. D. Price (Eds.), Transitions to agriculture in prehistory (pp. 81 95). Monographs in World Archaeology 4. Madison: Prehistory Press.

Lacan, M., Keyser, C., Ricaut, F. X., Brucato, N., Duranthon, F., Guilaine, J., et al. (2011). Ancient DNA reveals male diffusion through the Neolithic Mediterranean route. Proceedings of the National Academy of Sciences, 108(24), 97889791.

Lago, M., Duarte, C., Valera, A., Albergaria, J., Almeida, F., \& Carvalho, A. F. (1998). Povoado dos Perdigões (Reguengos de Monsaraz): Dados preliminares dos trabalhos arqueológicos realizados em 1997. Revista Portuguesa de Arqueologia, 1(1), 45152.

Lalueza Fox, C. (1996). Physical anthropological aspects of the Mesolithic Neolithic transition in the Iberian Peninsula. Current Anthropology, 37(4), 689695.

Lalueza, C., \& González, A. (1998). On chronology versus geography in the Iberian Mesolithic Neolithic transition. Current Anthropology, 39(4), 511512.

Lemmen, C., Gronenborn, D., \& Wirtz, K. (2011). A simulation of the Neolithic transition in Western Eurasia. Journal of Archaeological Science, 38, 34593470.

Lewthwaite, J. (1986). The transition to food production: A Mediterranean perspective. In M. Zvelebil (Ed.), Hunters in transition: Mesolithic societies of temperate Eurasia and their transition to farming (pp. 53 66). Cambridge: Cambridge University Press. 
López Sáez, J. A., López Merino, L., \& Pérez Díaz, S. (2008). Crisis climáticas en la prehistoria de la Península Ibérica: El evento 8200 CAL. BP como modelo. In S. Rovira, M. García, M. Gener, \& I. Montero (Eds.), Actas VII Congreso Ibérico de Arqueometría (pp. 77 86), 810 octubre 2007, Madrid.

Lubell, D., Jackes, M., Schwarcz, H., Knyf, M., \& Meiklejohn, C. (1994). The Mesolithic Neolithic transition in Portugal: Isotopic and dental evidence of diet. Journal of Archaeological Science, 21, 201216.

Malmström, H., Gilbert, M. T., Thomas, M. G., Brandstrom, M., Stora, J., Molnar, P., et al. (2009). Ancient DNA reveals lack of continuity between Neolithic hunter gatherers and contemporary Scandinavians. Current Biology, 19, 17581762.

Manen, C., Marchand, G., \& Carvalho, A. F. (2007). Le Néolithique ancien de la péninsule Ibérique : Vers une nouvelle évaluation du mirage africain? In Congrès du Centenaire (2007): Un siècle de con struction du discours scientifique en Préhistoire (pp. 133 151), Société préhistorique française, Paris.

Manen, C., \& Perrin, T. (2009). Réflexions sur la genèse du Cardial 'franco ibérique'. In De Méditerranée et d'ailleurs... Mélanges offerts à Jean Guilaine (pp. 427 443). Archives d'Écologie Préhistorique, Toulouse.

Manen, C., \& Sabatier, P. (2003). Chronique radiocarbone de la néolithisation en Méditerranée nord occidentale. Bulletin de la Société préhistorique française, 100(3), 479504.

Martí, B. (1977). Cova de l'Or (Beniarrés Alicante) (Vol. 1). Serie de Trabajos Varios del SIP 51, Valencia.

Martí, B., Arias Gago, A., Martínez, R., \& Juan Cabanilles, J. (2001). Los Tubos de Hueso de la Cova de l'Or (Beniarrés, Alicante): Instrumentos Musicales en el Neolítico Antiguo de la Península Ibérica. Trabajos de Prehistoria, 58(2), 4167.

Martí, B., \& Hernández, M. (1988). El Neolitic Valenciá: Art Rupestre i Cultura Material. Valencia: Servei d'Investigació Prehistórica.

Martí, B., \& Juan Cabanilles, J. (1997). Epipaleolíticos y Neolíticos: Población y Territorio en el Proceso de Neolitización de la Península Ibérica. Espacio, Tiempo y Forma. Serie I, Prehistoria y Arqueología, 10, 215264.

Martí, B., Pascual, V., Gallart, M. D., López, P., Pérez, M., Acuña, J.D., et al. (1980). Cova de l’Or (Beniarrés Alicante) (Vol. 2). Serie de Trabajos Varios del SIP 65, Valencia.

Martín, A., Edo, M., Tarrús, J., \& Clop, X. (2010). Le Néolithique ancien de Catalogne $\left(\mathrm{VI}^{\mathrm{e}}\right.$ première moitié du $\mathrm{V}^{\mathrm{e}}$ millénaire av. J. C.): Les séquences chronoculturelles. In C. Manen, F. Convertini, D. Binder, \& I. Sénépart (Eds.), Premières sociétés paysannes de Méditerranée occidentale: Structures des productions céramiques (pp. 197 214). Mémoire LI. Paris: Société préhistorique française.

Martínez, G., Afonso, J. A., Cámara, J. A., \& Molina, F. (2010). Contextualización cronológica y análisis tecno tipológico de los artefactos tallados del Neolítico antiguo de los Castillejos (Montefrío, Gra nada). In J. F. Gibaja, \& A. F. Carvalho (Eds.), Os Últimos Caçadores Recolectores e as Primeiras Comunidades Productoras do Sul da Península Ibérica e do Norte de Marrocos (pp. 163 171). Promontoria Monográfica 15. Faro: Universidade do Algarve.

McClure, S. B., Molina Balaguer, L., \& Bernabeu, J. (2008). Neolithic rock art in context: Landscape history and the transition to agriculture in Mediterranean Spain. Journal of Anthropological Archaeology, 27, 326337.

McGlade, J. (1999). Arqueología, dinámica no lineal y discurso histórico. Trabajos de Prehistoria, 56(2), 518.

Morales, J. I., Fontanals, M., Oms, F. X., \& Vergès, J. M. (2010). La chronologie du Néolithique ancien cardial du nord est de la péninsule Ibérique: Datations, problematique et méthodologie. L'Anthro pologie, 114, 427444.

Muñoz, A. (1972). Análisis de carbono 14 sobre muestras recogidas por el Instituto de Arqueología de la Universidad de Barcelona. Pyrenae, 8, 147150.

Natali, E. (2010). Typologie des décors de la céramique imprimée archaïque du sud est de l'Italie. In C. Manen, F. Convertini, D. Binder, \& I. Sénépart (Eds.), Premières sociétés paysannes de Méditerranée occidentale: Structures des productions céramiques (pp. 43 55). Mémoire LI. Paris: Société préhis torique française.

Oosterbeek, L. (2001). Re thinking the Mesolithic Neolithic transition in the Iberian Peninsula: A view from the West. Documenta Praehistorica, 28, 7584.

Oross, K., \& Bánffy, E. (2009). Three successive waves of Neolithisation: LBK development in Trans danubia. Documenta Praehistorica, 36, 175189.

Orozco, T. (2000). Aprovisionamiento e Intercambio: Análisis Petrológico del Utillaje Pulimentado en la Prehistoria Reciente del País Valenciano (España). BAR S867 International Series, Oxford.

Pallarés, M., Bordas, A., \& Mora, R. (1997). El Proceso de neolitización en los Pirineos orientales: Un modelo de continuidad entre los cazadores recolectores neolíticos y los primeros grupos agropastoriles. Trabajos de Prehistoria, 54(1), 121144. 
Pearce, M. (2008). Structured deposition in Early Neolithic Northern Italy. Journal of Mediterranean Archaeology, 21(1), 1933.

Peña Chocarro, L. (2007). Early agriculture in central and southern Spain. In S. Colledge \& J. Conolly (Eds.), The origins and spread of domestic plants in southwest Asia and Europe (pp. 173 187). Walnut Creek: Left Coast Press.

Peña Chocarro, L., Zapata, L., García, J., González, M., Sesma, J., \& Straus, L. G. (2005). The spread of agriculture in northern Iberia: New archaeobotanical data from El Mirón cave (Cantabria) and the open air site of Los Cascajos (Navarra). Vegetation History and Archaeobotany, 14, 268278.

Pinhasi, R., \& Pluciennik, M. (2004). A regional biological approach to the spread of farming in Europe. Current Anthropology, 45(supplement), 5982.

Price, B. J. (1977). Shifts in production and organization: A cluster interaction model. Current Anthro pology, 18(2), 209233.

Price, T. D., \& Gebauer, A. B. (1992). The final frontier: Foragers to farmers in southern Scandinavia. In A. B. Gebauer \& T. D. Price (Eds.), Transitions to agriculture in prehistory (pp. 97 116). Madison: Prehistory Press.

Ramis, D. (2010). From colonisation to habitation: Early cultural adaptations in the Balearic Bronze Age. In P. Van Dommelen \& A. B. Knapp (Eds.), Material connections in the ancient Mediterranean: Mobility, materiality and mediterranean identities (pp. 64 84). London: Routledge.

Reimer, P. J., Baillie, M. G. L., Bard, E., Bayliss, A., Beck, J. W., Bertrand, C. J. H., et al. (2004). IntCal04 terrestrial radiocarbon age calibration, $026 \mathrm{cal}$ kyr BP. Radiocarbon, 46(3), 10291058.

Renfrew, C. (1982). Polity and power: Interaction, intensification and exploitation. In C. Renfrew \& M. Wagstaff (Eds.), An Island polity: The archaeology of exploitation in Melos (pp. 264 290). Cambridge: Cambridge University Press.

Richards, M., Côrte Real, H., Forster, P., Macaulay, V., Wilkinson Herbots, H., Demaine, A., et al. (1996). Paleolithic and Neolithic lineages in the European mitochondrial gene pool. American Journal of Human Genetics, 59, 185203.

Richards, M., Macaulay, V., Hickey, E., Vega, E., Sykes, B., Guida, V., et al. (2000). Tracing European founder lineages in the Near Eastern mtDNA pool. American Journal of Human Genetics, 67, 12511276.

Richards, M. P., Schulting, R., \& Hedges, R. (2003). Sharp shift in diet at onset of Neolithic. Nature, 425, 366.

Robb, J. (2007). The early Mediterranean village: Agency, material culture, and social change in Neolithic Italy. Cambridge: Cambridge University Press.

Rodanés, J. M., \& Ramón, N. (1995). El Neolítico Antiguo en Aragón: Hábitat y territorio. Zephyrus, 48, 101128.

Rodríguez, Á. L., Alonso, C., \& Velázquez, J. (1995). La difusión occidental de las especies domésticas: Una alternativa a la 'ola de avance'. I Congrès del Neolitic a la Peninsula Ibèrica (Gavá Bellaterra, 1995). Rubricatum, 1(2), 835839.

Rojo, M., Kunst, M., Garrido, R., García, I., \& Morán, G. (2008). Paisajes de la memoria: Asentamientos del neolítico antiguo en el Valle de Ambrona (Soria, España), Serie Arte y Arqueología 23. Valladolid: Universidad de Valladolid.

Román, M. P., Martínez, C., Sánchez, L., Pérez, A. D., \& Cassinello, S. (1995). El neolítico en la cuenca alta del río Almanzora (Almería): Una revisión crítica. I Congrés del Neolític a la Península Ibèrica (Gavà Bellaterra, 1995). Rubricatum, 1(2), 613618.

Rootsi, S., Magri, C., Kivisild, T., Benuzzi, G., Help, H., Bermisheva, M., et al. (2004). Phylogeography of Y chromosome haplogroup I reveals distinct domains of prehistoric gene flow in Europe. American Journal of Human Genetics, 75, 128137.

Sampietro, M. L., Lao, O., Caramelli, D., Lari, M., Pou, R., Martí, M., et al. (2007). Palaeogenetic evidence supports a dual model of Neolithic spreading into Europe. Proceedings of the Royal Society of Bio logical Sciences, 274, 21612167.

Semino, O., Magri, Ch., Benuzzi, G., Lin, A., Al Zahery, N., Battaglia, V., et al. (2004). Origin, diffusion, and differentiation of $\mathrm{Y}$ chromosome haplogroups $\mathrm{E}$ and $\mathrm{J}$ : Inferences on the Neolithization of Europe and later migratory events in the Mediterranean area. American Journal of Human Genetics, 74, 10231034.

Shennan, S., \& Edinborough, K. (2007). Prehistoric population history: From the Late Glacial to the Late Neolithic in Central and Northern Europe. Journal of Archaeological Science, 34, 13391345.

Sherratt, A. (2004). Fractal farmers: Patterns of Neolithic origin and dispersal. In J. Cherry, C. Scarre, \& S. Shennan (Eds.), Explaining social change: Studies in Honour of Colin Renfrew (pp. 53 63). Cambridge: McDonald Institute for Archaeological Research, University of Cambridge.

Simoni, L., Calafell, F., Pettener, D., Bertranpetit, J., \& Barbujani, G. (2000). Geographic patterns of mtDNA diversity in Europe. American Journal of Human Genetics, 66, 262278. 
Skeates, R. (2003). Radiocarbon dating and interpretations of the Mesolithic Neolithic transition in Italy. In A. Ammerman \& P. Biagi (Eds.), The widening harvest. The Neolithic transition in Europe: Looking back, looking forward (pp. 157 187). Colloquia and conference papers 6. Boston: Archaeological Institute of America.

Soares, P., Achilli, A., Semino, O., Davies, W., Macaulay, V., Bandelt, H. J., et al. (2010). The archae ogenetics of Europe. Current Biology, 20, 174183.

Stika, H. P. (2005). Early Neolithic agriculture in Ambrona, Provincia Soria, central Spain. Vegetation History and Archaeobotany, 14(3), 189197.

Stiner, M. C., Bicho, N. F., Lindly, J., \& Ferring, R. (2003). Mesolithic to Neolithic transitions: New results from shell middens in the western Algarve, Portugal. Antiquity, 77(295), 7586.

Tozzi, C. (2002). Ripa Tetta. Puglia. In M. A. Fugazzola Delpino, A. Pessina, \& V. Tiné (Eds.), Le ceramiche impresse nel Neolitico antico (pp. 579 588). Roma: Italia e Mediterraneo, Istituto Polig rafico e Zecca dello Stato.

Utrilla, P. (2002). Epipaleolíticos y neolíticos del valle del Ebro. Saguntum Extra, 5, 179208.

Van Willigen, S. (2007). Entre Toscane et Provence: Le néolithique ancien corse dans son contexte Méditerranéen. In Corse et Sardaigne préhistoriques: Relations et échanges dans le contexte médi terranéen (pp. 59 77). Documents Préhistoriques 22. Paris: CTHS.

Van Willigen, S., Hajdas, I., \& Bonani, G. (2008). Nouvelles données concernant la chronologie interne du cardial franco ibérique en France méditerranéenne. In M. Hernández, J. Soler, \& J. López (Eds.), Actas del IV Congreso del Neolítico Peninsular II (pp. 365 373). Alicante: Museo Arqueológico de Alicante.

Vergés, J., Allué, E., Angelucci, D., Burjachs, F., Carrancho, A., Cebriá, A., et al. (2008). Los niveles neolíticos de la cueva de El Mirador (Sierra de Atapuerca, Burgos): Nuevos datos sobre la implan tación y el desarrollo de la economía agropecuaria en la Submeseta Norte. In M. Hernández, J. Soler, \& J. López (Eds.), Actas del IV Congreso del Neolitico Peninsular II (pp. 418 427). Alicante: Museo Arqueológico de Alicante.

Vicent, J. M. (1990). El neolítico: Transformaciones sociales y económicas. Boletín de antropología americana, 24, 3162.

Vicent, J. M. (1997). The island filter model revisited. In M. S. Balmuth, A. Gilman, \& L. Prados Torreira (Eds.), Encounters and transformations: The archaeology of Iberia in transition (pp. 1 13). Mono graphs in Mediterranean Archaeology 7. Sheffield: Sheffield Academic Press.

Watkins, T. (2008). Supra regional networks in the Neolithic of southwest Asia. Journal of World Pre history, 21, 139171.

Watkins, T. (2010). New light on Neolithic revolution in southwest Asia. Antiquity, 84, 621634.

Weninger, B., Alram Stern, E., Bauer, E., Clare, L., Danzeglocke, U., Jöris, O., et al. (2006). Climate forcing due to the $8200 \mathrm{cal}$ yr BP event observed at Early Neolithic sites in the eastern Mediterranean. Quaternary Research, 66, 401420.

Zapata Peña, L. (2007). First farmers along the coast of the Bay of Biscay. In S. Colledge \& J. Conolly (Eds.), The origins and spread of domestic plants in Southwest Asia and Europe (pp. 189 208). Walnut Creek: Left Coast Press.

Zapata, L., Peña Chocarro, L., Pérez, G., \& Stika, H. P. (2004). Early Neolithic agriculture in the Iberian Peninsula. Journal of World Prehistory, 18(4), 283325.

Zilhão, J. (1998a). On logical and empirical aspects of the Mesolithic Neolithic transition in the Iberian Peninsula. Current Anthropology, 39(5), 690698

Zilhão, J. (1998b). A passagem do Mesolítico ao Neolítico na costa do Alentejo. Revista Portuguesa de Arqueologia, 1(1), 2744

Zilhão, J. (2001). Radiocarbon evidence for maritime pioneer colonization at the origins of farming in West Mediterranean Europe. Proceedings of the National Academy of Sciences, 98(24), 1418014185.

Zilhão, J. (2003). The Neolithic transition in Portugal and the role of demic diffusion in the spread of agriculture across West Mediterranean Europe. In A. Ammerman \& P. Biagi (Eds.), The widening harvest. The Neolithic transition in Europe: Looking back, looking forward (pp. 207 223). Colloquia and conference papers 6. Boston: Archaeological Institute of America.

Zilhão, J. (2009). The Early Neolithic artifact assemblage from the Galeria da Cisterna (Almonda karstic system, Torres Novas, Portugal). In De Méditerranée et d'ailleurs... Mélanges offerts à Jean Guilaine (pp. 821 835). Toulouse: Archives d'Écologie Préhistorique.

Zilhão, J. (2011). Time is on my side.... In A. Hadjikoumis, E. Robinson, and S. Viner (Eds.), The dynamics of Neolithisation in Europe (pp. 46 65). Studies in Honour of Andrew Sherratt. Oxford: Oxbow Books.

Zvelebil, M. (1989). On the transition to farming in Europe, or what was spreading with the neolithic: A reply to Ammerman (1989). Antiquity, 63(239), 379383.

Zvelebil, M., \& Dolukhanov, P. (1991). The transition to farming in Eastern and Northern Europe. Journal of World Prehistory, 5(3), 233278. 